\title{
Enantioselective reductive oligomerization of carbon dioxide into L-erythrulose via a chemo-enzymatic catalysis
}

Sarah Desmons, ${ }^{*},+, \neq$ Katie Grayson-Steel, ${ }^{\ddagger}$ Nelson Nuñez-Dallos, ${ }^{\dagger, \S}$ Laure Vendier, ${ }^{\dagger}$ John Hurtado,§ Pere Clapés," Régis Fauré,‡ Claire Dumon,‡ Sébastien Bontemps ${ }^{*}, \dagger$

† LCC-CNRS, Université de Toulouse, CNRS, F-31077 Toulouse Cedex 4, France.

‡ TBI, Université de Toulouse, CNRS, INRAE, INSA, 31077 Toulouse, France

${ }^{\S}$ Department of Chemistry, Universidad de los Andes, Carrera 1 No. 18A-12, 111711, Bogotá, Colombia

"Biological Chemistry Department, Instituto de Química Avanzada de Cataluña, IQAC-CSIC, Jordi Girona 18-26, 08034 Barcelona, Spain 
1. General procedures

1-1. X-ray structures determination 3

1-2. Semi-preparative HPLC 3

2. NMR and IR spectra of compound 1

3. Stability of 1 and formaldehyde release $\quad 8$

3-1. Stability of 1 under air $\quad 8$

3-2. Stability of 1 in $\mathrm{D}_{2} \mathrm{O} \quad 8$

3-3. Stability of 1 with 10 equiv. of $\mathrm{D}_{2} \mathrm{O}$ in THF- $d_{8} \quad 8$

3-4. Stability of 1 in buffer/THF mixture 11

4. Characterization of $\mathrm{Mes}_{2} \mathrm{BOH} \quad 12$

5. Synthesis of ${ }^{13} \mathrm{C}$-labeled imine from hydrolysis of $1-{ }^{13} \mathrm{C}$ and subsequent condensation reaction $\begin{array}{ll}\text { with aniline } & 14\end{array}$

$\begin{array}{lll}\text { 6. Protein expression and purification } & 16\end{array}$

6-1. Vector construction and mutagenesis 16

6-2. FSA A129S 18

$\begin{array}{llr}6-3 . & \text { FLS } & 18\end{array}$

6-4. $\quad$ FLS stability at $4{ }^{\circ} \mathrm{C} \quad 19$

7. FLS stability in the presence of organic co-solvents by Differential Scanning Fluorimetry (DSF) 20

8. FLS-catalyzed transformation of commercial formaldehyde 21

9. $\quad$ FLS-catalyzed synthesis of $3-{ }^{13} \mathrm{C}$ from $1-{ }^{13} \mathrm{C} \quad 24$

10. FLS-catalyzed synthesis of 3 from $\mathrm{CO}_{2}$ in a one-pot process 27

11. FSA A129S-catalyzed synthesis of L-erythrulose from commercial DHA and formaldehyde 28

12. FLS/FSA A129S cascade reaction with commercial HCHO 30

13. FSA A129S-catalyzed synthesis of L-erythrulose from commercial DHA and 1

14. Characterization of isolated $4-{ }^{13} \mathrm{C} \quad 34$

15. Synthesis of L-erythrulose from FLS/FSA A129S cascade reaction with 1

16. Calibration curves 38 
17. Retention time of the standards

18. Purification of FLS and FSA A129S: SDS-PAGE analysis 42

19. References 


\section{General procedures}

\section{1-1. X-ray structures determination}

The crystals were kept in their mother liquor until they were dipped in perfluoropolyether oil and their structure determined. The chosen crystals were mounted on a Mitegen micromount and quickly cooled down to either $100 \mathrm{~K}$ or $180 \mathrm{~K}$. The selected crystals were mounted on a Bruker Kappa APEX II using a micro-focus molybdenum $\mathrm{K} \alpha$ radiation $(\lambda=0.71073 \AA)$ equipped with graphite monochromator which attached with an Oxford Cryosystems Cooler Device (compound 3), or on a Gemini Agilent diffractometer using a graphite-monochromated $\mathrm{Cu}-\mathrm{K} \alpha$ Enhance radiation $(\lambda=1.54184 \AA)$ and equipped with an Oxford Instrument Cooler Device (compound 1). The unit cell determination and data integration were carried out using APEXII $^{1}$ (Mes 2 B-OH) and CrysAlisPro 1.171.38.43² (compound 1). The structures have been solved by Direct Methods using SHELXS, ${ }^{3}$ and refined by least-squares procedures with SHELXL-2016 ${ }^{7}$ included in the software packages WinGX version 1.63. ${ }^{4}$ Atomic Scattering Factors were taken from the International tables for X-Ray Crystallography. ${ }^{5}$ Absorption correction was done using multi-scan DENZO/SCALEPACK (Otwinowski \& Minor, 1997) method. ${ }^{6}$ All hydrogen atoms were geometrically placed and refined using a riding model, excepted for the atoms $\mathrm{H} 21$ and $\mathrm{H} 31$ of $\mathrm{Mes}_{2} \mathrm{~B}-\mathrm{OH}$ which were located by Fourier Differences and refined isotropically.

All non-hydrogen atoms were anisotropically refined. Drawings of molecules have been performed with the program Ortep-3 for Windows. ${ }^{7}$ Details of the structure solution and refinements are given in the CIF file.

\section{1-2. Semi-preparative HPLC}

Semi-preparative HPLC was performed on a Shodex Asahipak NH2P-50 10E column, 250 x $10.0 \mathrm{~mm}$ column. The machine used was the Thermo Scientific Dionex Ultimate 3000. Samples $(100 \mu \mathrm{L})$ were injected and eluted with the following conditions: isocratic solvent system $70 \%$ acetonitrile / $30 \%$ water, 30 minutes run time per injection, flow rate $1.0 \mathrm{~mL} \cdot \mathrm{min}^{-1}$, detection using ultraviolet (UV) detector at $192 \mathrm{~nm}$, column temperature $26^{\circ} \mathrm{C}$. The fractions containing the target product were recovered manually and pooled together. 


\section{NMR and IR spectra of compound 1}

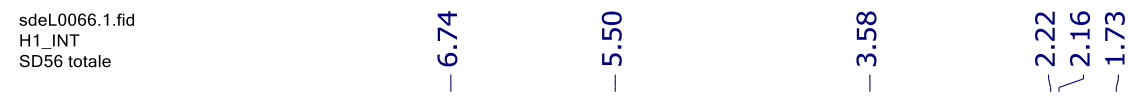

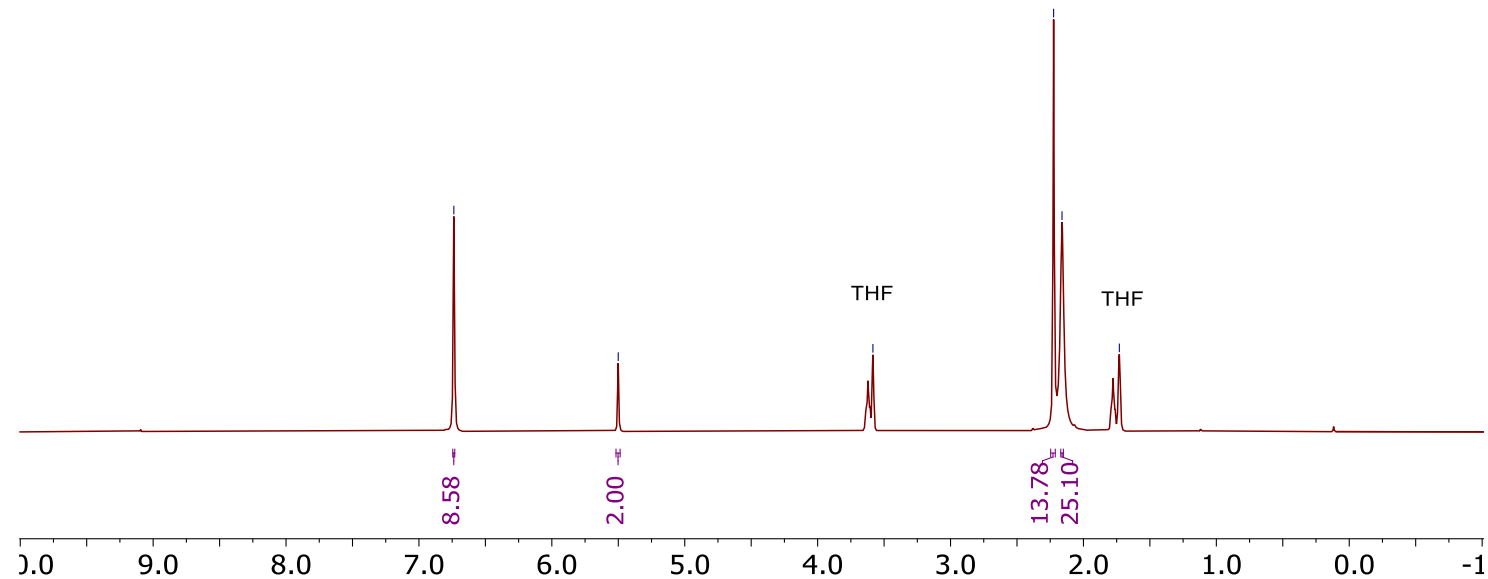

Figure S1. ${ }^{1} \mathrm{H}$ NMR spectrum of $\mathbf{1}$ in THF- $d 8$ at $298 \mathrm{~K}$.

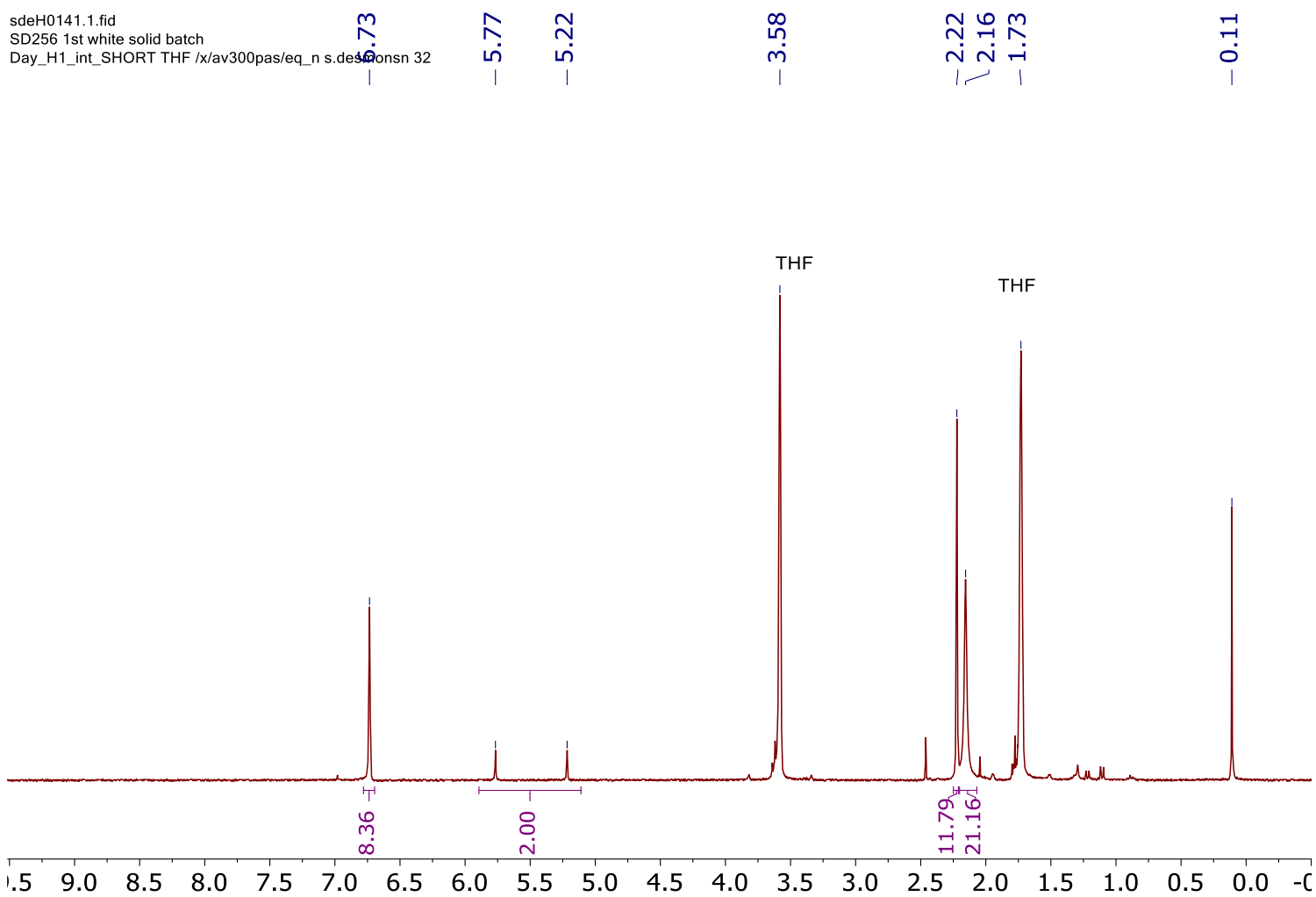

Figure S2. ${ }^{1} \mathrm{H}$ NMR spectrum of $1-{ }^{\mathbf{1 3}} \mathbf{C}$ in THF- $d_{8}$ at $298 \mathrm{~K}$. 
岌岌岌岌

$\stackrel{\infty}{\infty} \stackrel{\infty}{\circ} \infty$

กิ 곡
○ 0
㞬岂崖堊崖崖

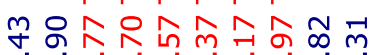
งั่

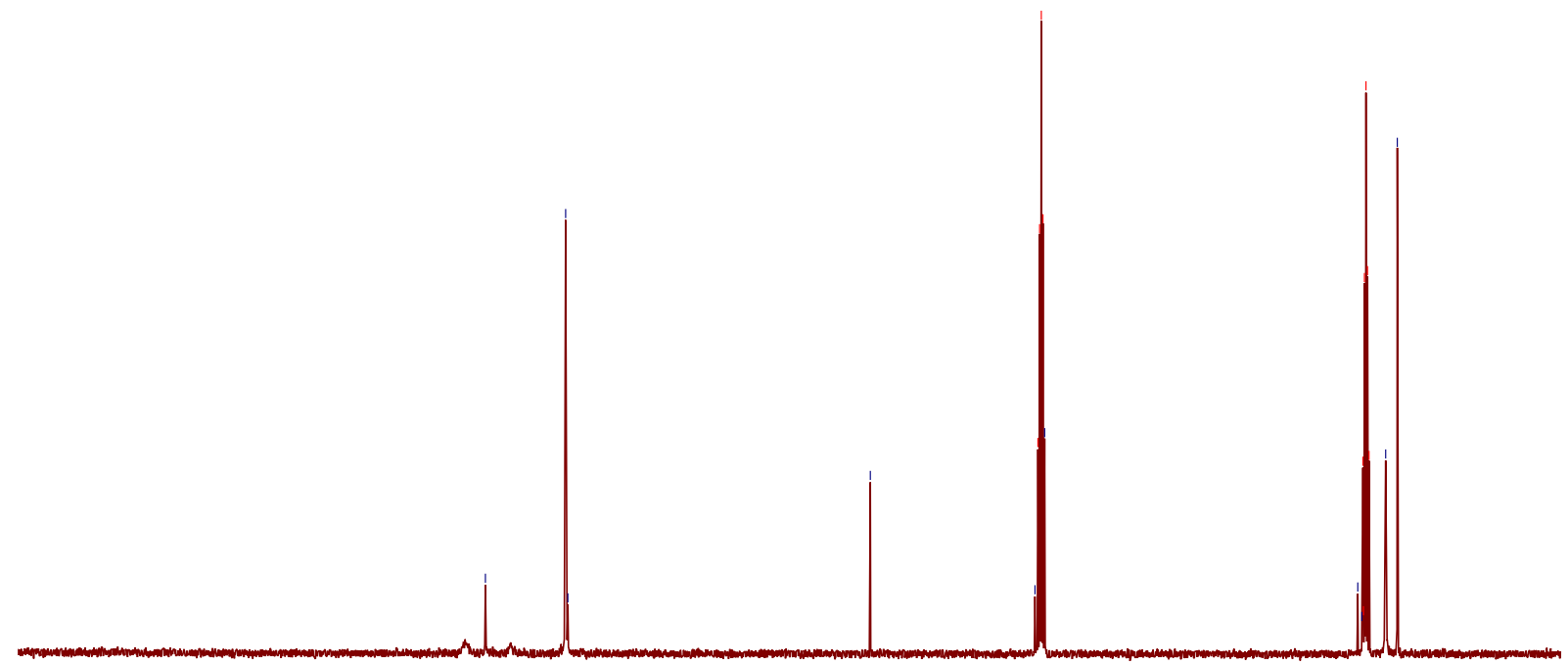

$\begin{array}{llllllllllllllllllll}00 & 190 & 180 & 170 & 160 & 150 & 140 & 130 & 120 & 110 & 100 & 90 & 80 & 70 & 60 & 50 & 40 & 30 & 20 & 10\end{array}$

Figure S3. ${ }^{13} \mathrm{C}\left\{{ }^{1} \mathrm{H}\right\}$ NMR spectrum of $\mathbf{1}$ in THF- $d_{8}$ at $298 \mathrm{~K}$.

sdeH0141.3.fid

Day_C13_DECOUPLE_H1_SHORT THF /x/av300pas/eq_n s.desmonsn 32

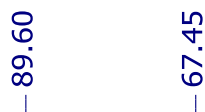

ஸे

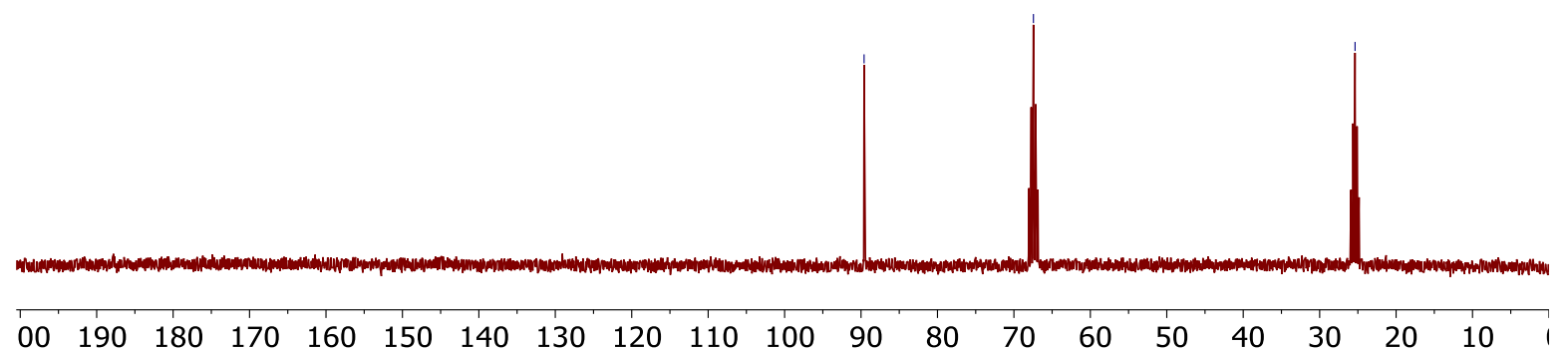

Figure S4. ${ }^{13} \mathrm{C}\left\{{ }^{1} \mathrm{H}\right\}$ NMR spectrum of $\mathbf{1 -}{ }^{\mathbf{1 3}} \mathbf{C}$ in THF- $d_{8}$ (32 scans) at $298 \mathrm{~K}$. 
sdeL0066.2.fid

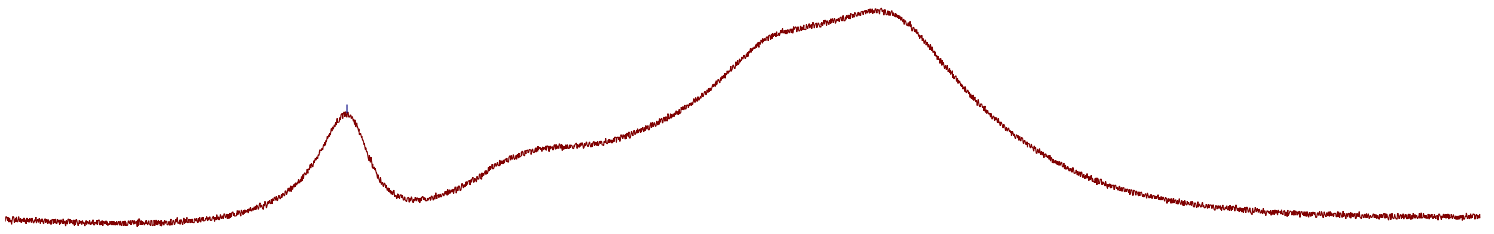

Figure S5. ${ }^{11} \mathrm{~B}\left\{{ }^{1} \mathrm{H}\right\}$ NMR spectrum of $\mathbf{1}$ in THF- $d_{8}$ at $298 \mathrm{~K}$.

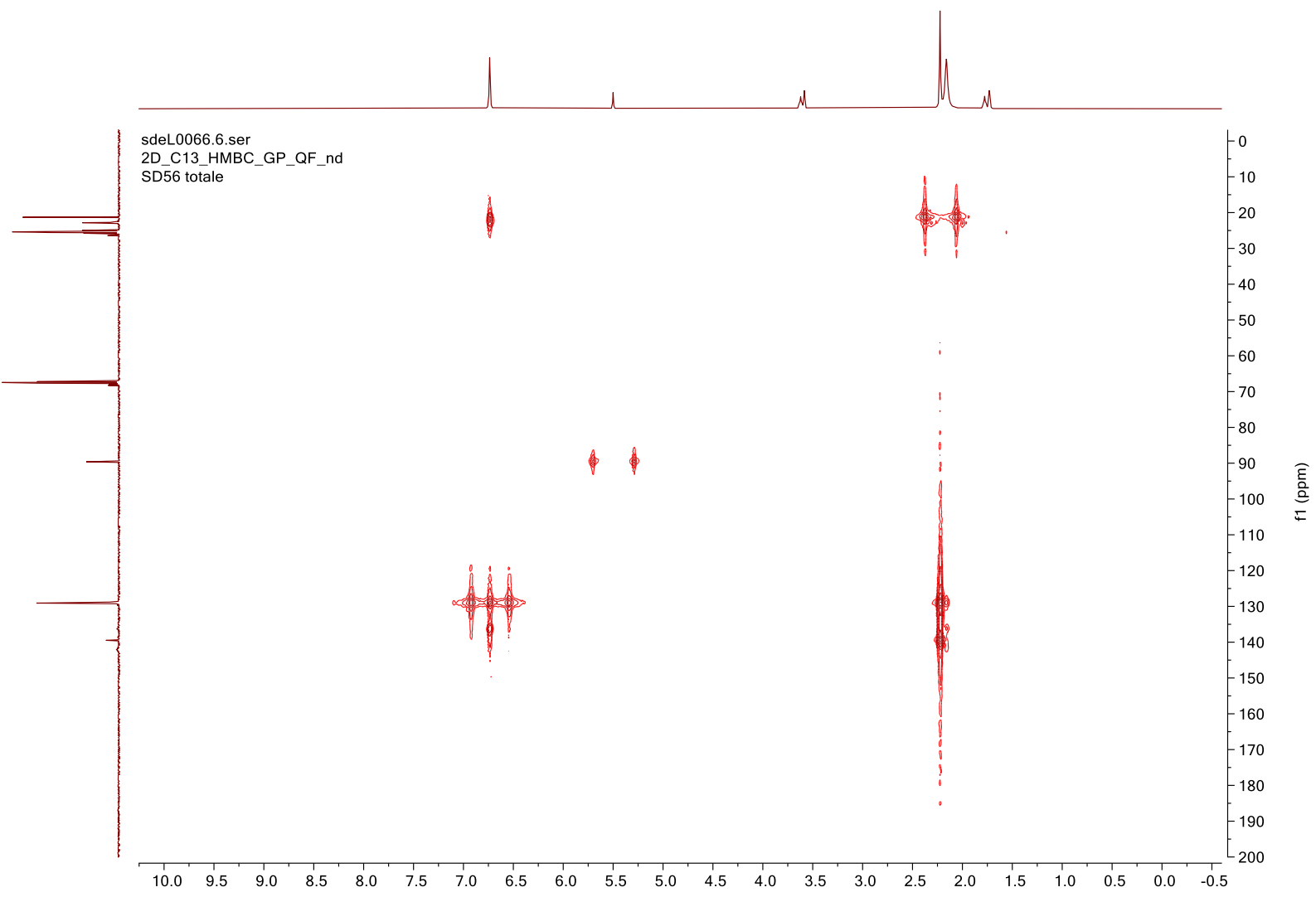

Figure S6. 2D ${ }^{13} \mathrm{C}\left\{{ }^{1} \mathrm{H}\right\} /{ }^{1} \mathrm{H}$ HMBC NMR spectrum of 1 in THF- $d 8$ at $298 \mathrm{~K}$. 


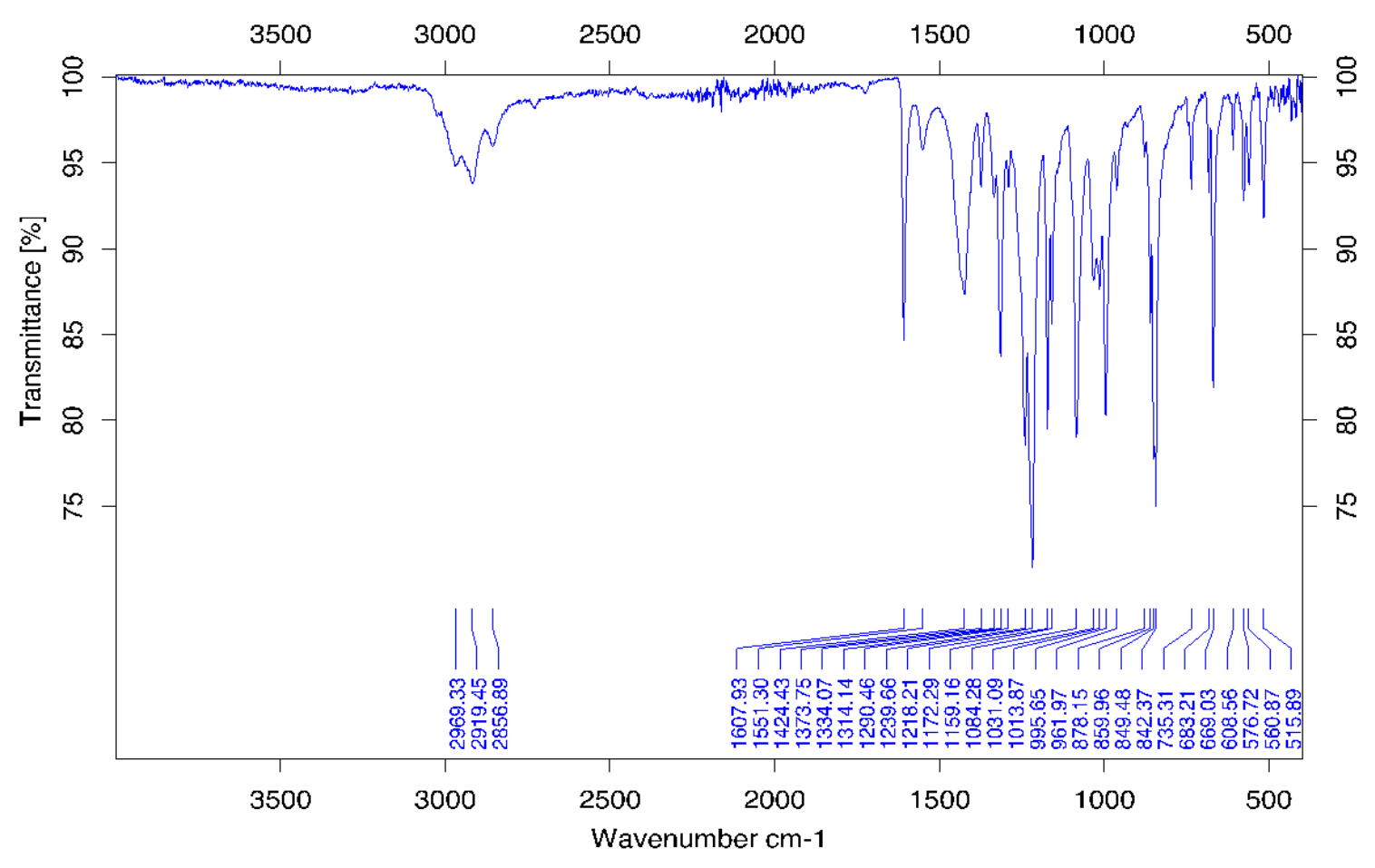

Figure S7. Solid state ATR infrared spectrum of isolated $\mathbf{1 .}$ 


\section{Stability of 1 and formaldehyde release}

\section{3-1. Stability of 1 under air}

A solution of $1(10 \mathrm{mg}, 0.018 \mathrm{mmol})$ in THF- $d_{8}$ or in benzene- $d_{6}(c a .0 .6 \mathrm{~mL})$ in an NMR tube equipped with a J. Young valve, with hexamethylbenzene present as internal standard, was exposed to air and allowed to stand at room temperature. The sample was monitored by ${ }^{1} \mathrm{H}$ NMR spectroscopy showing quantitative conversion of $\mathbf{1}$ into formaldehyde after approximatively 20 days at room temperature. In THF- $d_{8}$, formaldehyde was observed with a characteristic signal at $\delta=+9.57 \mathrm{ppm}$ corresponding to monomeric formaldehyde and between $\delta=+5.5-4.0 \mathrm{ppm}$ attributed to paraformaldehyde.

\section{3-2. Stability of 1 in $\mathrm{D}_{2} \mathrm{O}$}

$1(10 \mathrm{mg}, 0.018 \mathrm{mmol})$ was placed in degassed $\mathrm{D}_{2} \mathrm{O}(\mathrm{ca} .0 .6 \mathrm{~mL})$ in an NMR tube equipped with a J. Young valve and was left at room temperature. 1 was found to precipitate in $\mathrm{D}_{2} \mathrm{O}$. The sample was monitored by ${ }^{1} \mathrm{H}$ NMR spectroscopy which showed no other signal than the residual $\mathrm{H}_{2} \mathrm{O}$ peak. After 2 months, the mixture was dried under reduced pressure and the totality of $\mathbf{1}$ was recovered according to ${ }^{1} \mathrm{H}$ and ${ }^{11} \mathrm{~B}$ NMR analyses in THF- $d 8$.

\section{3-3. Stability of 1 with 10 equiv. of $\mathrm{D}_{2} \mathrm{O}$ in THF- $d_{8}$}

A solution of $1(10 \mathrm{mg}, 0.018 \mathrm{mmol})$ in THF- $d_{8}(c a .0 .6 \mathrm{~mL})$ in an NMR tube equipped with a J. Young valve, with hexamethylbenzene present as internal standard, was exposed to $c a$. 10 equivalents of $\mathrm{D}_{2} \mathrm{O}$. The solution was allowed to stand at room temperature and monitored by ${ }^{1} \mathrm{H}$ NMR spectroscopy showing the release of formaldehyde, paraformaldehyde and the corresponding borylated by-product $\mathrm{Mes}_{2} \mathrm{BOH}$ after less than 2 hours (Figures S8 and S9). 


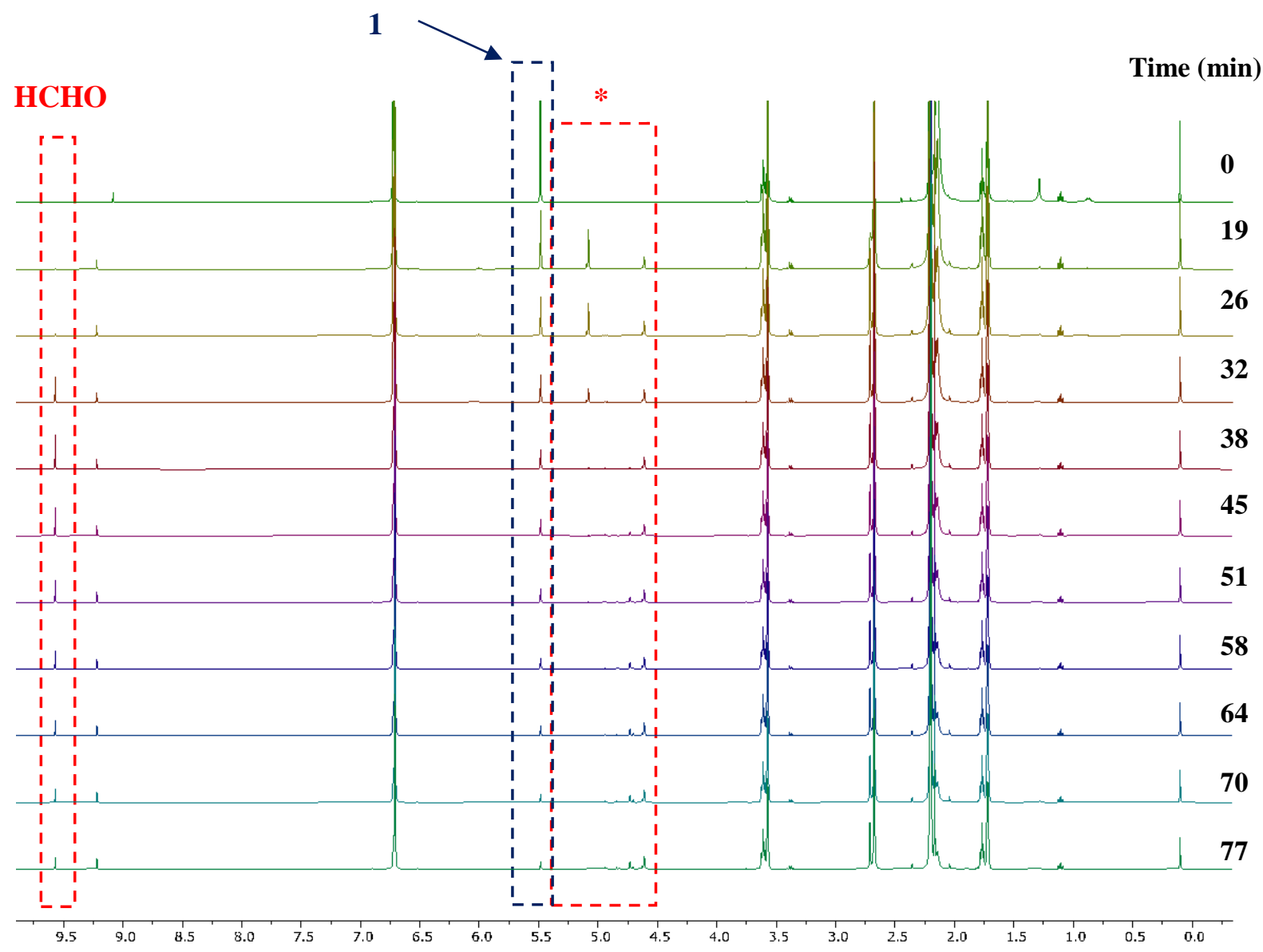

Figure S8. Stacking of ${ }^{1} \mathrm{H}$ NMR spectra in THF- $d_{8}$ showing the evolution of $\mathbf{1}$ (characteristic acetal signal in blue box) and formation of formaldehyde (monomeric "HCHO" and oligomeric and diol "*" forms in red boxes) in the presence of 10 equiv. of $\mathrm{H}_{2} \mathrm{O}$.

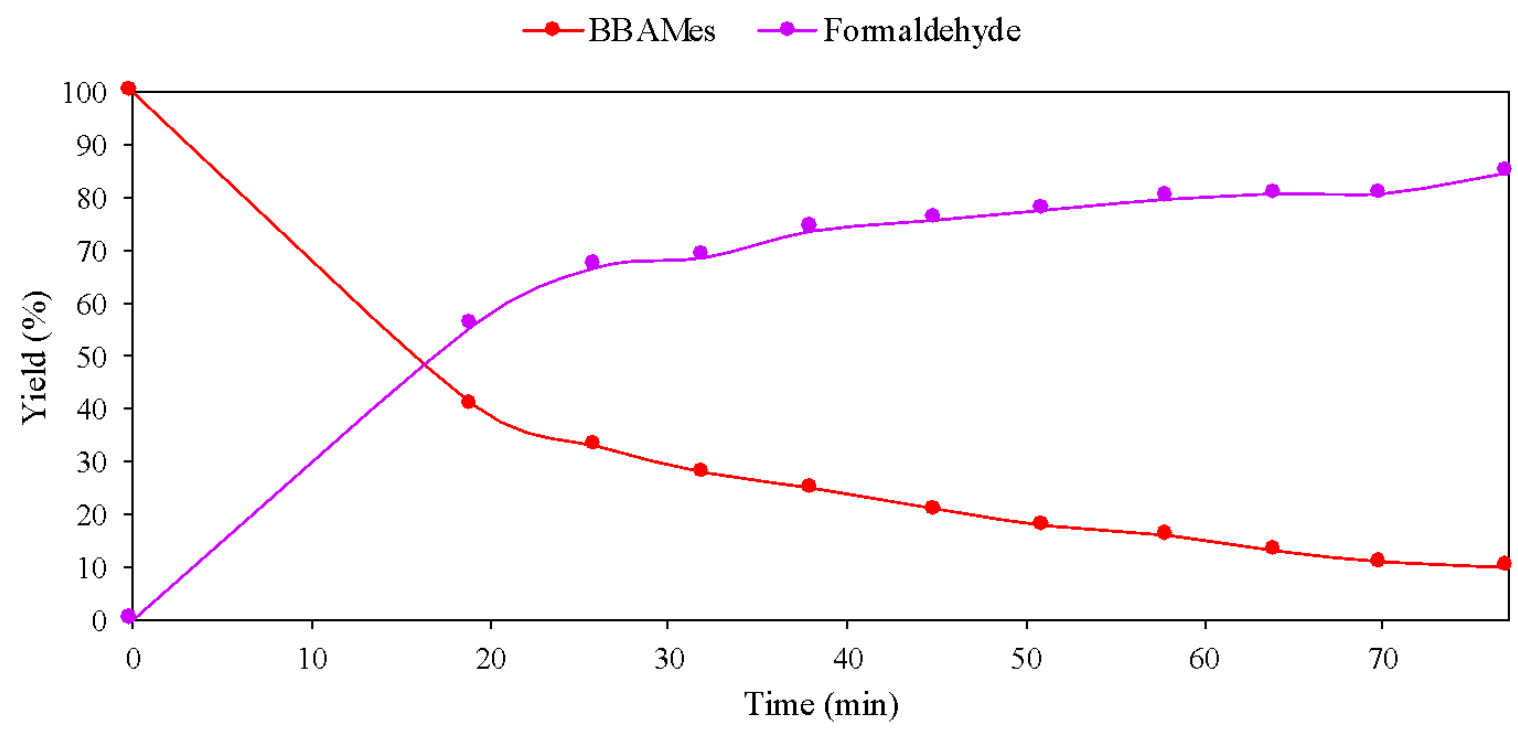

Figure S9. Consumption of $\mathbf{1}$ and formation of formaldehyde overtime. The yields were determined by ${ }^{1} \mathrm{H}$ NMR spectroscopy by integration relative to the internal standard. 
Following the procedure described above, the reaction was performed using $1 \mathbf{- 1 3}^{\mathbf{1 3}} \mathbf{C}$. The reaction was monitored by ${ }^{1} \mathrm{H}$ NMR spectroscopy after 0,1 and 2 hours. The spectra obtained are depicted in Figures S10 and S11.

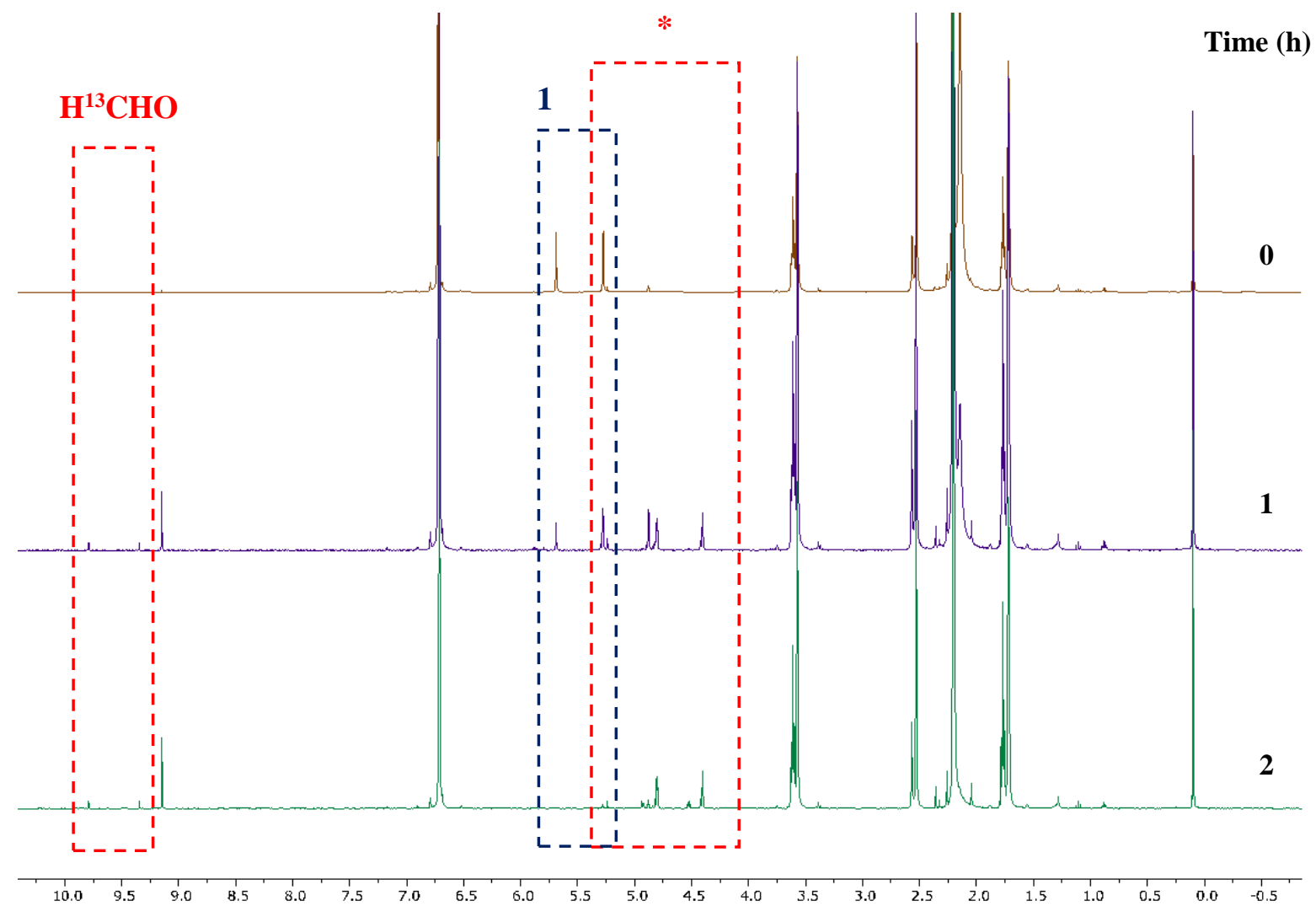

Figure S10. Consumption of $1 \mathbf{1}^{13} \mathbf{C}$ (in blue box) and formation of ${ }^{13} \mathrm{C}$-labeled formaldehyde (HCHO) and oligomeric and diol forms (*, in red boxes) monitored by ${ }^{1} \mathrm{H}$ NMR spectroscopy in THF- $d_{8}$ in the presence of 10 equiv. of $\mathrm{H}_{2} \mathrm{O}$. 


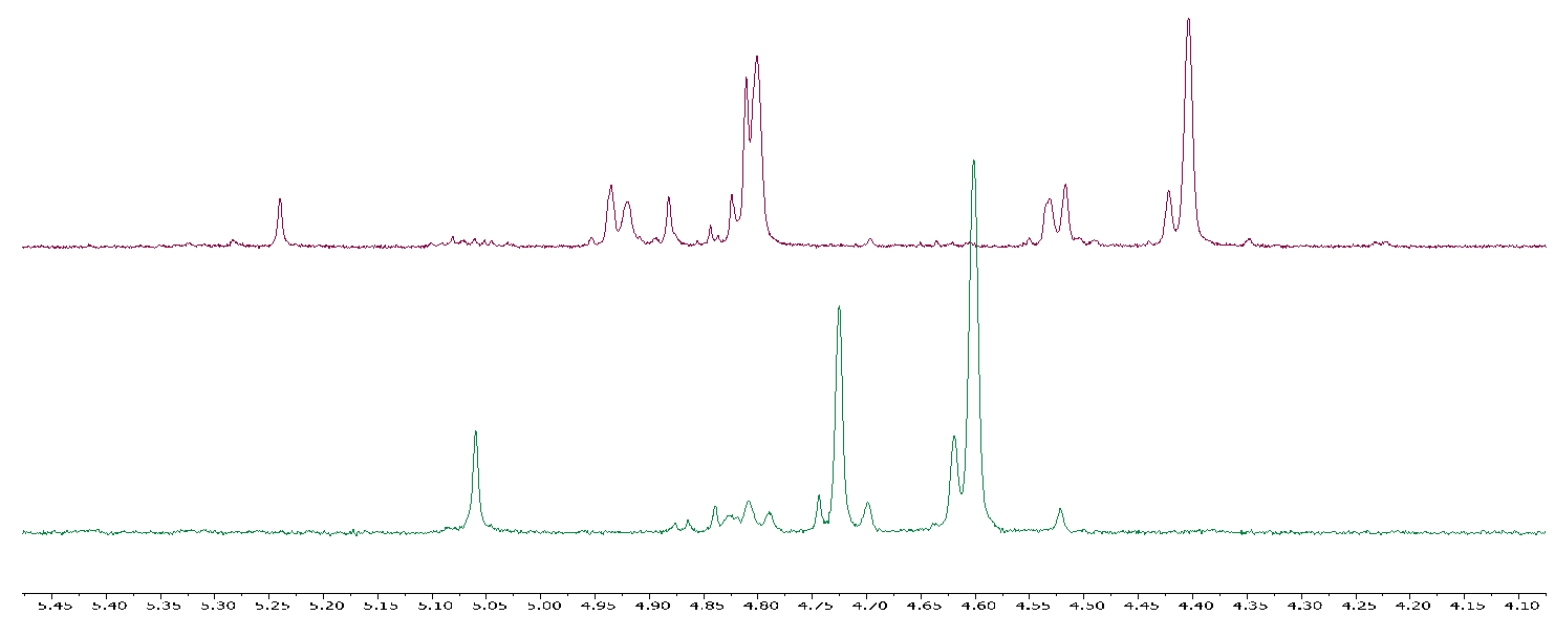

Figure S11. ${ }^{1} \mathrm{H}$ (top) and ${ }^{1} \mathrm{H}\left\{{ }^{13} \mathrm{C}\right\}$ (bottom) NMR spectra (selected region: $\delta=+5.5-4.0 \mathrm{ppm}$ ) obtained after hydrolysis of $\mathbf{1 -}^{\mathbf{1 3}} \mathbf{C}$ in THF- $d 8$.

\section{3-4. Stability of 1 in buffer/THF mixture}

The buffer used to perform the bioconversion reactions was: triethanolamine (TEA) buffer (25 $\mathrm{mM}, \mathrm{pH}$ 7.0) containing $1 \mathrm{mM} \mathrm{MgSO}_{4}$ and $0.1 \mathrm{mM}$ TPP. The reaction buffer was freshly prepared before each reaction. $1(4.4 \mathrm{mg}, 0.008 \mathrm{mmol}, 10 \mathrm{mM})$ was added in solid form in a 2 mL Eppendorf tube. The required volume of $\operatorname{THF}(0,10,20$ or $30 \%)$ was added and the reaction buffer was added to a final volume of $0.8 \mathrm{~mL}$. The samples were placed at $30{ }^{\circ} \mathrm{C}$ and shaken at $900 \mathrm{rpm}$. Aliquots of $0.1 \mathrm{~mL}$ were taken after $0,1,2,4,7,24$ and 48 hours. The aliquots were heated at $98{ }^{\circ} \mathrm{C}$ for 3 minutes, centrifuged for 2 minutes at $12000 \mathrm{x} \mathrm{g}$ and the supernatant solution was analyzed by analytical HPLC. The results obtained are combined in Table S1.

Table S1. Hydrolysis of $\mathbf{1}$ into formaldehyde in different buffer/THF mixture.

\begin{tabular}{cccccccc}
\hline \multirow{2}{*}{ Conditions } & \multicolumn{7}{c}{ Yield $^{\mathrm{a}} \mathbf{( \% )}$ of HCHO released overtime } \\
\cline { 2 - 8 } & $<\mathbf{1} \mathbf{~ m i n}$ & $\mathbf{1 ~ h}$ & $\mathbf{2} \mathbf{~ h}$ & $\mathbf{4} \mathbf{~ h}$ & $\mathbf{7} \mathbf{~ h}$ & $\mathbf{2 4} \mathbf{~ h}$ & $\mathbf{4 8} \mathbf{~ h}$ \\
\hline $\mathbf{0 \%}$ THF & 0 & 1 & 0 & 0 & 2 & 14 & 57 \\
$\mathbf{1 0 \%}$ THF & 37 & 51 & 54 & 50 & 49 & 58 & 47 \\
$\mathbf{2 0 \%}$ THF & 79 & 78 & 82 & 87 & 78 & 88 & 82 \\
$\mathbf{3 0 \%}$ THF & 99 & 95 & 98 & 99 & 94 & 99 & 94 \\
\hline
\end{tabular}

a Yields are calculated by HPLC. 


\section{Characterization of $\mathrm{Mes}_{2} \mathrm{BOH}$}

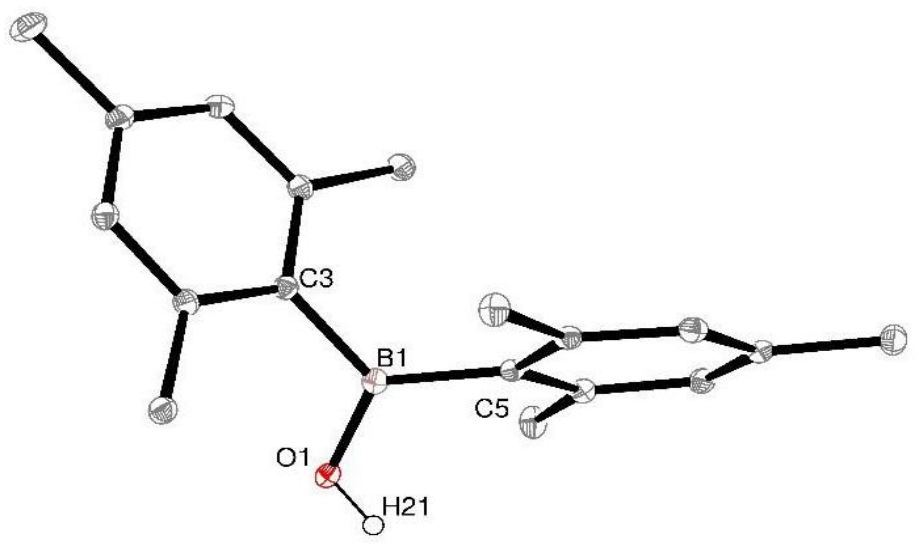

Figure S12. ORTEP view of X-ray structure of $\mathrm{Mes}_{2} \mathrm{BOH}$ at $50 \%$ thermal ellipsoid probability level. All the hydrogen atoms were omitted for clarity except $\mathrm{BO} H$.

sdeG0030.1.fid

SD41 White solid obtained after wash with cold pentane colourless sol Day H1 int SHORT THF /x/av400pas/data/eq o/nmr s.desmons 2

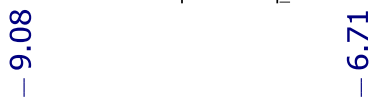

$$
\text { - }
$$

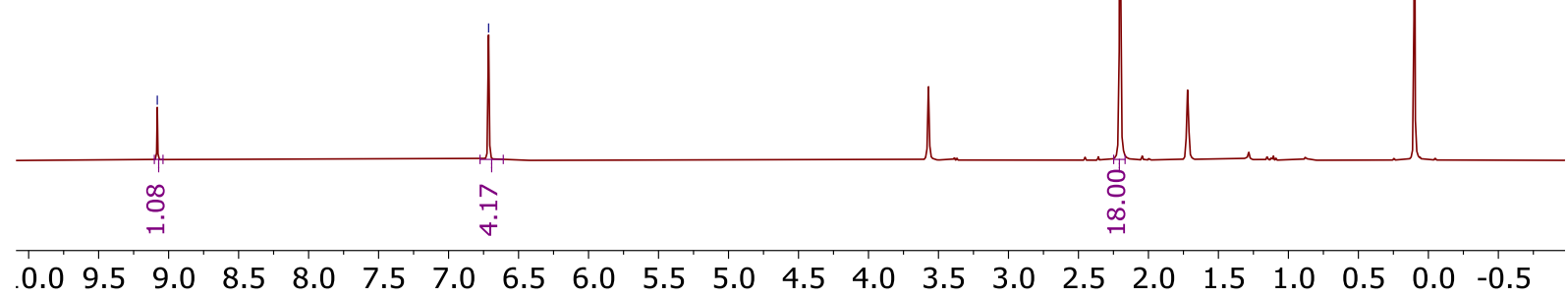

Figure S13. ${ }^{1} \mathrm{H}$ NMR spectrum of $\mathrm{Mes}_{2} \mathrm{BOH}$ in THF- $d_{8}$ at $298 \mathrm{~K}$. 


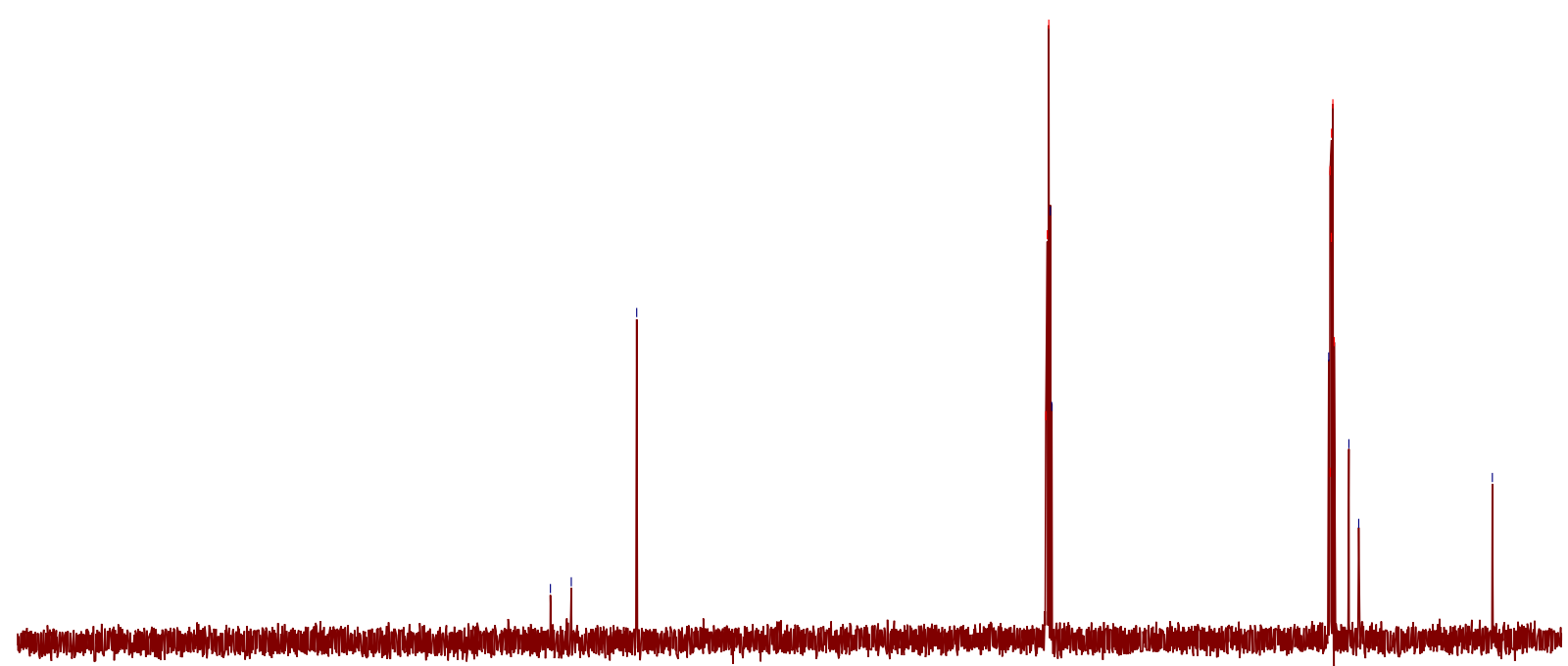

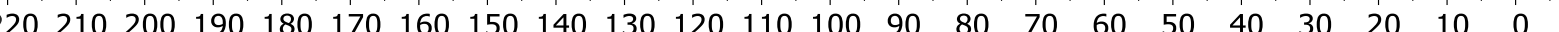

Figure S14. ${ }^{13} \mathrm{C}\left\{{ }^{1} \mathrm{H}\right\}$ NMR spectrum of $\mathrm{Mes}_{2} \mathrm{BOH}$ in THF- $d_{8}$ at $298 \mathrm{~K}$.

sdeG0037.1.fid

SD41 118

Day_B11_DECOUPLE_H1_SHORT THF / / /av400pas/data/eq_o/nmr s.desmons 2

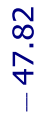

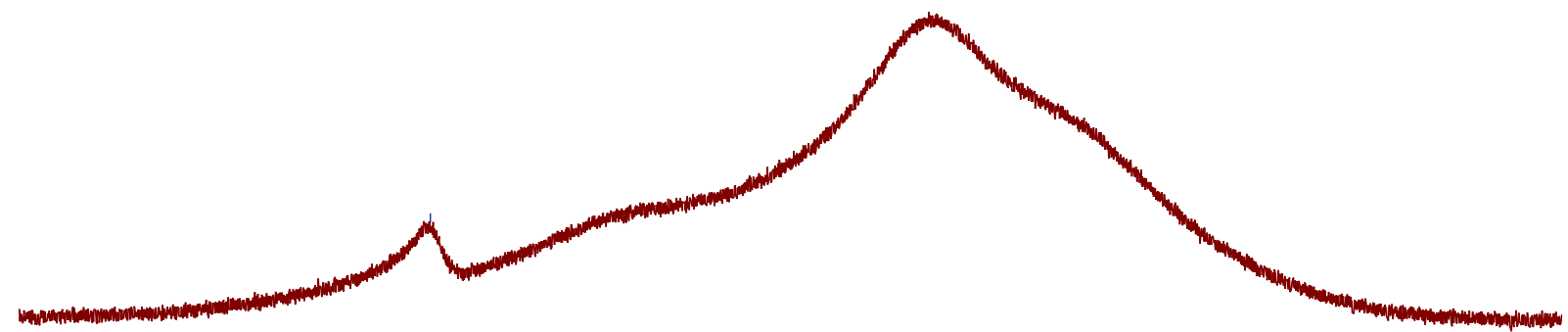

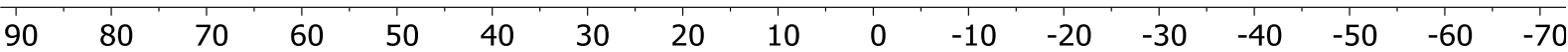

Figure S15. ${ }^{11} \mathrm{~B}\left\{{ }^{1} \mathrm{H}\right\}$ NMR spectrum of $\mathrm{Mes}_{2} \mathrm{BOH}$ in THF- $d_{8}$ at $298 \mathrm{~K}$. 


\section{Synthesis of ${ }^{13} \mathrm{C}$-labeled imine from hydrolysis of $1-{ }^{13} \mathrm{C}$ and subsequent condensation}

reaction with aniline

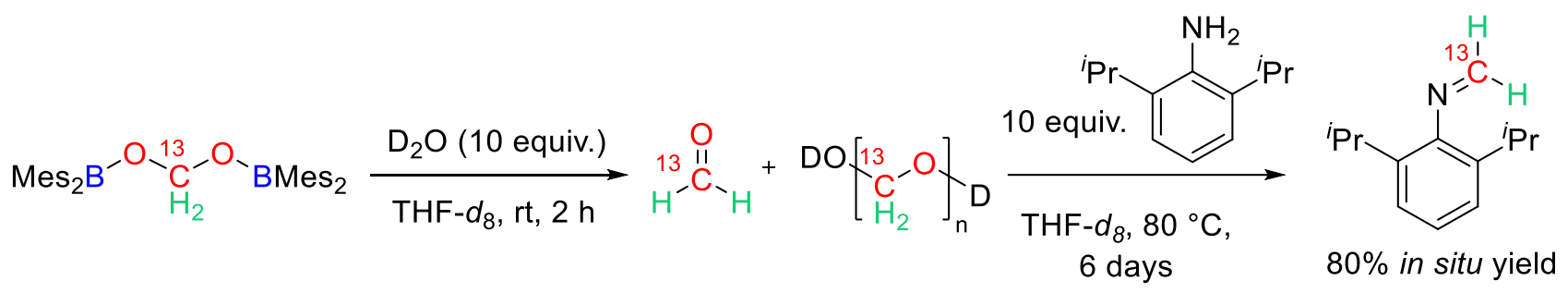

10 equiv. of $\mathrm{D}_{2} \mathrm{O}$ was added to a solution of $\mathbf{1 - 1 3}^{\mathbf{1 3}} \mathbf{C}(10 \mathrm{mg}, 0.018 \mathrm{mmol})$ in THF- $d_{8}(c a .0 .6 \mathrm{~mL})$ in an NMR tube equipped with a J. Young valve, with hexamethylbenzene present as internal standard. After the disappearance of NMR signals corresponding to $\mathbf{1 -}^{\mathbf{1 3}} \mathbf{C}$ (2 hours at room temperature), 10 equiv. of freshly distilled 2,6-bis(diisopropyl)phenylamine $(0.034 \mathrm{~mL}, 0.18$ mmol, 10 equivalents) were added to the solution. The reaction mixture was heated at $80{ }^{\circ} \mathrm{C}$ in an oil bath and monitored by NMR spectroscopy revealing the formation of the corresponding ${ }^{13} \mathrm{C}$-labeled imine after 6 days in 80\% in situ yield. ${ }^{1} \mathbf{H}$ NMR (THF- $d_{8}, 298 \mathrm{~K}, 400 \mathrm{MHz}$ ): $\delta$ $7.73\left(\mathrm{dd}, 1 \mathrm{H},{ }^{1} J_{\mathrm{C}-\mathrm{H}}=150.9 \mathrm{~Hz},{ }^{2} J_{\mathrm{H}-\mathrm{H}}=18.4 \mathrm{~Hz},{ }^{13} \mathrm{CH}_{2}\right), 7.30\left(\mathrm{dd}, 1 \mathrm{H},{ }^{1} J_{\mathrm{C}-\mathrm{H}}=132.0 \mathrm{~Hz},{ }^{2} J_{\mathrm{H}-\mathrm{H}}\right.$ $\left.=18.4 \mathrm{~Hz},{ }^{13} \mathrm{CH}_{2}\right) .{ }^{13} \mathrm{C}\left\{{ }^{1} \mathrm{H}\right\}$ NMR $\left(\mathrm{THF}-d_{8}, 298 \mathrm{~K}, 101 \mathrm{MHz}\right): \delta 156.5\left(\mathrm{~s},{ }^{13} \mathrm{CH}_{2}\right)$. The NMR data obtained are consistent with the ones reported in the literature. ${ }^{2}$ 


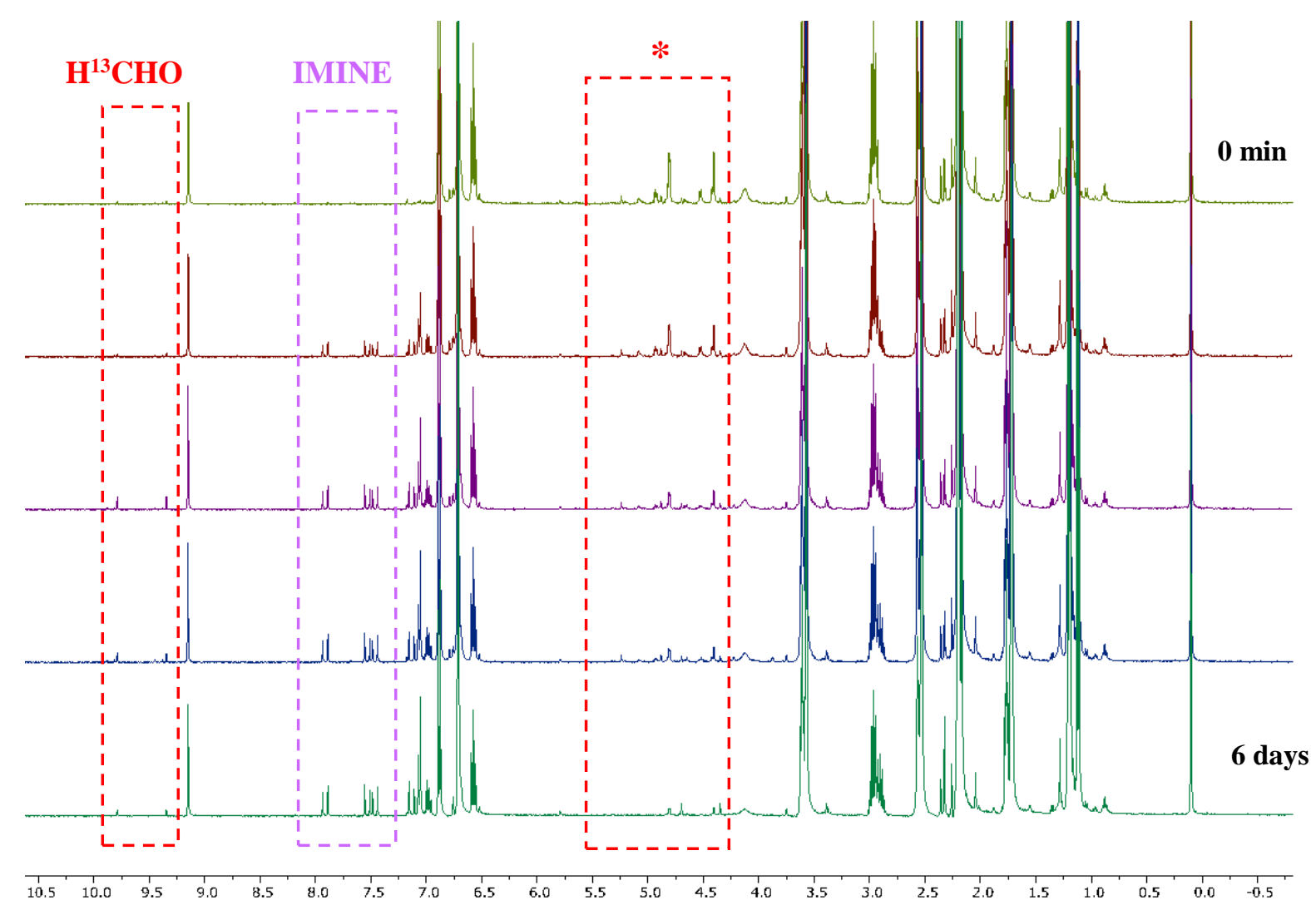

Figure S16. Stacking of ${ }^{1} \mathrm{H}$ NMR spectra in THF- $d_{8}$ at $298 \mathrm{~K}$ showing the consumption of formaldehyde released from $\mathbf{1 - 1 3}^{\mathbf{1 3}} \mathbf{C}$ (monomeric "HCHO" and oligomeric and diol "*” form in red boxes) and the formation of ${ }^{13} \mathrm{C}$-labeled imine (characteristic methylene signal in purple box). 


\section{Protein expression and purification}

Incubator Multitron Pro Infors HT were used for cell culture incubation. Cells were harvested with a Beckman Avanti J26 XP centrifuge using JA-10 or JA-25.50 fixed angle rotors. Protein concentration was determined using a Thermo Nanodrop 2000C UV-Vis spectrophotometer.

\section{6-1. Vector construction and mutagenesis}

The genes coding for D-fructose-6-phosphate aldolase from E. coli $(f s a)$ and formolase $(f l s)$ were cloned in pET-21a(+) in fusion with His6-tag generating SD1 and SD4 using the plasmids pQE $f s a$ and pSEVAfls as templates, respectively. FSA A129S was produced from SD3 obtained after site directed mutagenesis (SD2) and introduction of a STOP codon to remove the His6-tag fusion for a better stability of the enzyme (SD3) (Table S2).

DNA manipulations and bacterial transformations were performed according to the standard protocols or manufacturers' instructions. Mutagenesis was performed in a Bio-Rad thermocycler T100. The mutation was introduced using the Phusion ${ }^{\circledR}$ polymerase (NEB) and the primers reported in Table S1. E. Coli Stellar competent cells (Takara Bio) were used for transformation and plasmid preparation. The plasmid DNA was isolated with the QIAGEN spin miniprep kit. DNA sequencing analysis confirmed the expected mutation. 
Table S2. Strains, plasmids and oligonucleotides used in this study. Mutagenized codons are highlighted in bold and underlined.

\begin{tabular}{|c|c|c|}
\hline E. coli strains & Relevant genotype & Ref./Origin \\
\hline Stellar & 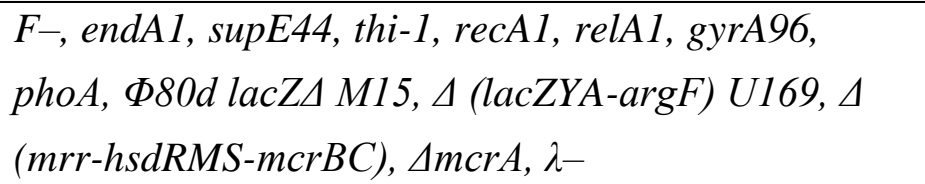 & Takara Bio \\
\hline BL21(DE3) & $F-o m p \mathrm{~T} h s d S_{B}\left(\mathrm{r}_{\mathrm{B}}{ }^{-} \mathrm{m}_{\mathrm{B}}{ }^{-}\right) g a l d c m(\mathrm{DE} 3)$ & - \\
\hline Plasmids & Relevant genetic characteristics & Ref./Origin \\
\hline pQE $f s a$ & $f s a$ gene $(660 \mathrm{bp})$ cloned in pQE40 & 8 \\
\hline pET-21a(+) & $\mathrm{P}_{\mathrm{T} 7}, \mathrm{Amp}^{\mathrm{r}}$, ori $i_{\mathrm{pBR} 322}$, ori f1, lacI, C-term His6-tag & Novagen \\
\hline SD1 & $\begin{array}{l}\text { fsa gene }(660 \mathrm{bp}) \text {, cloned in pET-21a(+) } \\
(\mathrm{NdeI} / \text { HindIII) in fusion with His6-tag in C-term. }\end{array}$ & This study \\
\hline SD2 & $\begin{array}{l}\text { SD1 mutated in A129S using primers FSA A129S } \\
\text { displayed below. }\end{array}$ & This study \\
\hline SD3 & $\begin{array}{l}\text { SD2 with stop codon introduced after the gene to } \\
\text { produce the FSA enzyme without His6-tag. }\end{array}$ & This study \\
\hline pSEVAfls & $f l s$ gene (1725 bp) cloned in pSEVA & 9 \\
\hline SD4 & $f l s$ gene $(1725 \mathrm{bp})$ cloned in pET-21a(+) (NdeI/XhoI) & This study \\
\hline Oligonucleotides & Oligonucleotide sequences $\left(5^{\prime} \rightarrow 3^{\prime}\right)$ & Ref./Origin \\
\hline $\begin{array}{l}\mathrm{pET}(\mathrm{NdeI}) f s a \\
\text { forward }\end{array}$ & $\begin{array}{l}\text { TAAGAAGGAGATATACATATGGAACTGTATC } \\
\text { TGGATACTTCAGACG }\end{array}$ & This study \\
\hline $\begin{array}{l}\mathrm{pET}(\text { HindIII }) f s a \\
\text { reverse }\end{array}$ & $\begin{array}{l}\text { TGCGGCCGCAAGCTTAATCGACGTTCTGCCA } \\
\text { AACGCTC }\end{array}$ & This study \\
\hline $\begin{array}{l}\mathrm{pET}(\mathrm{NdeI}) f l s \\
\text { forward }\end{array}$ & $\begin{array}{l}\text { TAAGAAGGAGATATACATATGGCTATGATTA } \\
\text { CTGGTGGTGAAC }\end{array}$ & This study \\
\hline pET(XhoI)fls reverse & $\begin{array}{l}\text { GTGGTGGTGCTCGAGCGCGCCGGATTGGAAA } \\
\text { TACAGATTC }\end{array}$ & This study \\
\hline FSA A129S forward & $\begin{array}{l}\text { GGTGCGGAATATGTTTCGCCTTACGTTAATC } \\
\text { G }\end{array}$ & This study \\
\hline FSA A129S reverse & $\begin{array}{l}\text { CGATTAACGTAAGGEGAAACATATTCCGCAC } \\
\text { C }\end{array}$ & This study \\
\hline STOP forward & $\begin{array}{l}\text { CGTTTGGCAGAACGTCGATTTAAAAGCTTGC } \\
\text { GGCC }\end{array}$ & This study \\
\hline STOP reverse & $\begin{array}{l}\text { GGCCGCAAGCTTITAAATCGACGTTCTGCCA } \\
\text { AACG }\end{array}$ & This study \\
\hline
\end{tabular}




\section{6-2. FSA A129S}

The plasmid SD3 was transformed into E. coli strain BL21(DE3). Cells were grown at $37{ }^{\circ} \mathrm{C}$ in LB medium $(200 \mathrm{~mL})$ containing ampicillin $\left(50 \mu \mathrm{g} . \mathrm{L}^{-1}\right)$ up to an optical density of 0.6 at 600 $\mathrm{nm}$. Protein expression was induced by addition of $0.2 \mathrm{mM}$ final concentration of IPTG at 16 ${ }^{\circ} \mathrm{C}$ overnight. Cells were harvested, suspended in triethanolamine (TEA) buffer $(25 \mathrm{mM}, \mathrm{pH}$ 7.0) and lysed via sonication. Cellular debris was removed by centrifugation at $39000 \mathrm{x}$ g for 30 minutes at $4{ }^{\circ} \mathrm{C}$. The clear supernatant was treated with heat-shock $\left(70{ }^{\circ} \mathrm{C}, 30\right.$ minutes $)$ and centrifuged at $30000 \mathrm{x}$ g for 30 minutes at $4{ }^{\circ} \mathrm{C}$. The supernatant was filtered through a 0.45 $\mu \mathrm{m}$ filter and purified using a Q Sepharose FF HP (GE Healthcare) column followed by size exclusion (GE HiLoad 16/600 Superdex 200 column). The purified protein was recovered in TEA buffer (25 mM, pH 7.0) containing $150 \mathrm{mM} \mathrm{NaCl}$ and finally lyophilized. Around $14 \mathrm{mg}$ of FSA A129S were recovered per $200 \mathrm{~mL}$ culture. The lyophilized enzyme was stored in the fridge at $4{ }^{\circ} \mathrm{C}$.

For enzyme assay, lyophilized FSA A129S was suspended in Milli-Q grade water and buffer exchange was performed using a PD-10 desalting column prepacked with Sephadex G-25 resin (GE Healthcare). The protein was recovered in TEA buffer (25 mM, pH 7.0) containing $1 \mathrm{mM}$ $\mathrm{MgSO}_{4}$ and $0.1 \mathrm{mM}$ TPP.

\section{6-3. FLS}

The plasmid SD4 was transformed into E. coli strain BL21(DE3). Cells were grown at $37{ }^{\circ} \mathrm{C}$ in TB medium $(200 \mathrm{~mL})$ containing ampicillin $\left(50 \mu \mathrm{g} . \mathrm{L}^{-1}\right)$ up to an optical density of 0.6 at 600 $\mathrm{nm}$. Protein expression was induced after lowering the temperature at $16^{\circ} \mathrm{C}$ with $1.0 \mathrm{mM}$ final concentration of IPTG overnight. Cells were harvested, suspended in PBS buffer (1X PBS: in 1L: $8 \mathrm{~g} \mathrm{NaCl}, 0.2 \mathrm{~g} \mathrm{KCl}, 1.44 \mathrm{~g} \mathrm{Na}_{2} \mathrm{HPO}_{4}, 0.24 \mathrm{~g}$ of $\mathrm{KH}_{2} \mathrm{PO}_{4}$, $\mathrm{pH} 7.4$ ) containing $1 \mathrm{mM} \mathrm{MgSO} 4$ and $0.1 \mathrm{mM}$ TPP and lysed using sonication. Cellular debris was removed by centrifugation at $39000 \mathrm{x}$ g for 30 minutes at $4{ }^{\circ} \mathrm{C}$. The clear supernatant was collected and loaded onto a $\mathrm{Co}^{2+}{ }_{-}$ NTA-agarose column (Takara Bio) pre-equilibrated with binding buffer (1X PBS buffer (pH 7.4) containing $1 \mathrm{mM} \mathrm{MgSO} 4$ and $0.1 \mathrm{mM} \mathrm{TPP})$. The retained proteins were recovered with elution buffer (1X PBS buffer (pH 7.4) containing $1 \mathrm{mM} \mathrm{MgSO}_{4}, 0.1 \mathrm{mM}$ TPP and $250 \mathrm{mM}$ imidazole). The eluted fraction containing purified protein was loaded onto a PD-10 desalting column. The protein was recovered in TEA buffer $(25 \mathrm{mM}, \mathrm{pH} 7.0)$ containing $1 \mathrm{mM} \mathrm{MgSO}_{4}$ and $0.1 \mathrm{mM}$ TPP. Around $7 \mathrm{mg}$ of FLS were recovered per $200 \mathrm{~mL}$ culture. FLS was stored at $4{ }^{\circ} \mathrm{C}$ in the reaction buffer until required. 


\section{6-4. FLS stability at $4{ }^{\circ} \mathrm{C}$}

To probe if FLS is stable after purification when stored at $4{ }^{\circ} \mathrm{C}$, we conducted the FLS-catalyzed formaldehyde oligomerization at days 1,2,3,4 and 7, by measuring the yield of DHA after 4 hours of reaction for each time point. The activity of FLS was assessed in a reaction mixture $(0.8 \mathrm{~mL})$ containing FLS $(20 \mu \mathrm{M}), 10 \mathrm{mM}$ formaldehyde and TEA buffer (25 mM, pH 7.0) containing $1 \mathrm{mM} \mathrm{MgSO}_{4}$ and $0.1 \mathrm{mM}$ TPP. The samples were placed at $30{ }^{\circ} \mathrm{C}$ and shaken at $900 \mathrm{rpm}$ for 4 hours. The sample was then heated at $98{ }^{\circ} \mathrm{C}$ for 3 minutes, centrifuged for 2 minutes at $30000 \mathrm{x} \mathrm{g}$ and the supernatant solution was analyzed by analytical HPLC. The results obtained are depicted in Figure S17 and showed no significant loss of activity after 7 days at $4{ }^{\circ} \mathrm{C}$ in the reaction buffer.

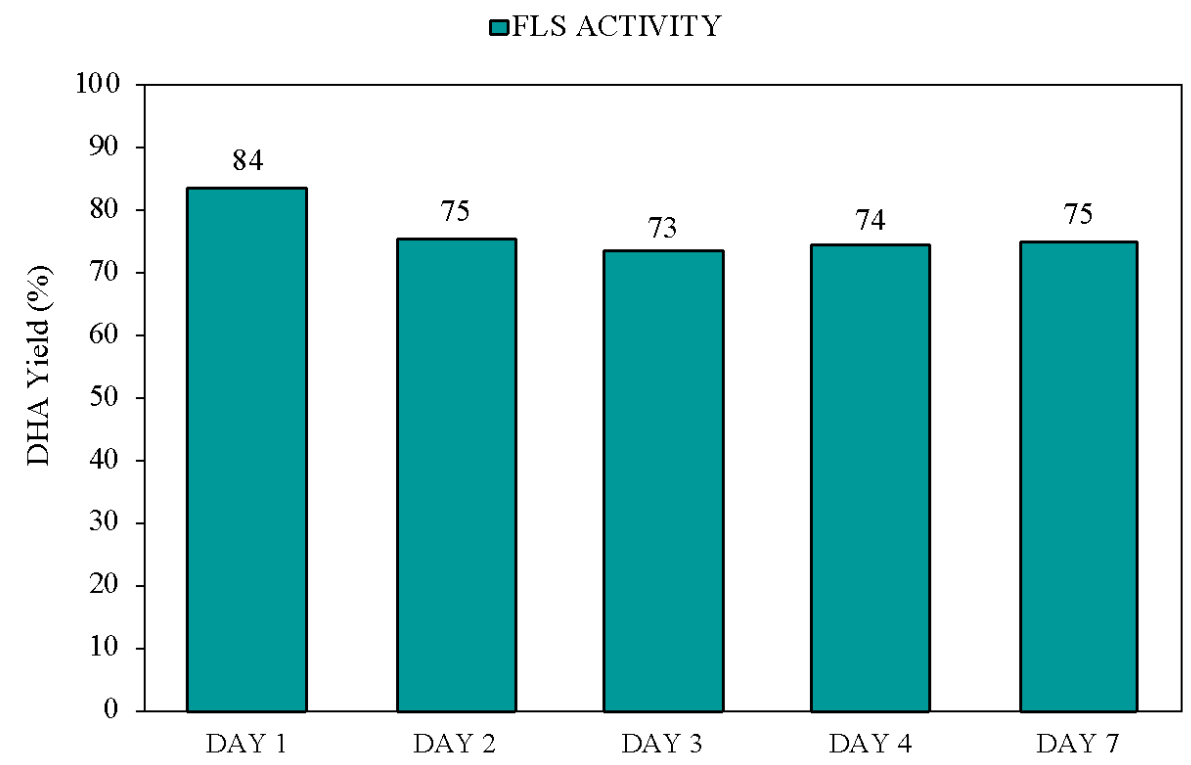

Figure S17. Yields of DHA for 5 reactions conducted at day 1, 2, 3, 4 and 7 of a FLS batch stored at $4{ }^{\circ} \mathrm{C}$. 


\section{FLS stability in the presence of organic co-solvents by Differential Scanning Fluorimetry (DSF)}

DSF experiments were performed with freshly purified FLS to follow its stability in the presence of five organic co-solvents: DMSO, THF, ACN, DMF and MeOH. The Tm value of FLS in TEA buffer (25 mM, pH 7.0) containing $1 \mathrm{mM} \mathrm{MgSO} 4$ and $0.1 \mathrm{mM} \mathrm{TPP}$ is $55.7^{\circ} \mathrm{C}$.

DSF was performed with $10 \mu \mathrm{M}$ of pure FLS in TEA buffer ( $25 \mathrm{mM}, \mathrm{pH} 7.0)$ containing $1 \mathrm{mM}$ $\mathrm{MgSO}_{4}$ and $0.1 \mathrm{mM}$ TPP, SYPRO orange (Life Technologies, stock of $5000 \mathrm{X}$ used as received) diluted 500 times and supplemented with final concentration of 5, 10, 20, 25 and 30\% of DMSO or THF, 5, 10, 15 and $20 \%$ of DMF or acetonitrile and 5 and $10 \%$ of methanol. A ramp from 20 to $100{ }^{\circ} \mathrm{C}$ was applied with $0.3{ }^{\circ} \mathrm{C}$ increments at a rate of $0.3{ }^{\circ} \mathrm{C}$ per second on a qPCR Bio Rad CFX96. All the solvents used were of analytical grade.

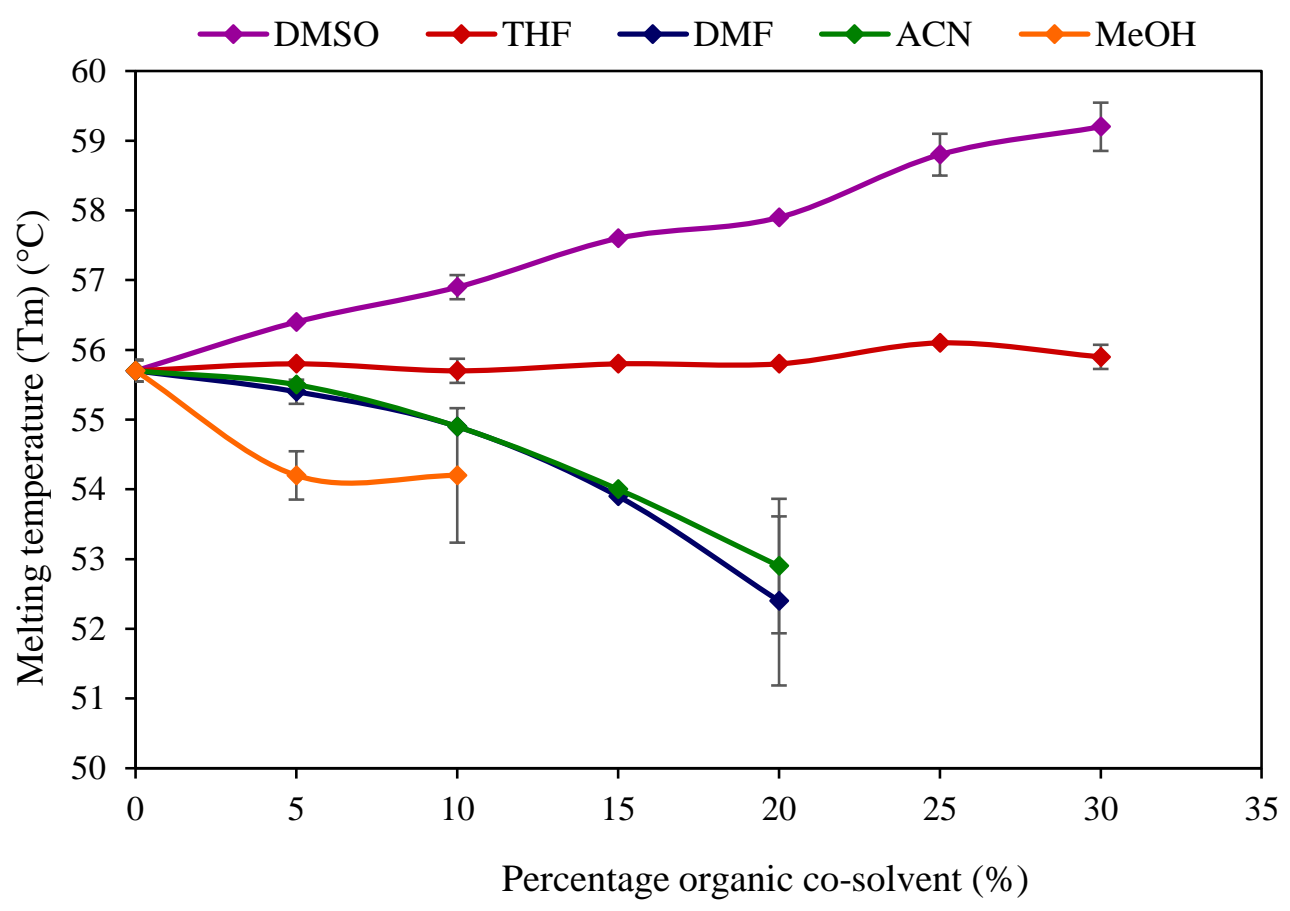

Figure S18. DSF-measured Tm value of FLS in the presence of DMSO, THF, DMF, ACN and $\mathrm{MeOH}$. 


\section{FLS-catalyzed transformation of commercial formaldehyde}

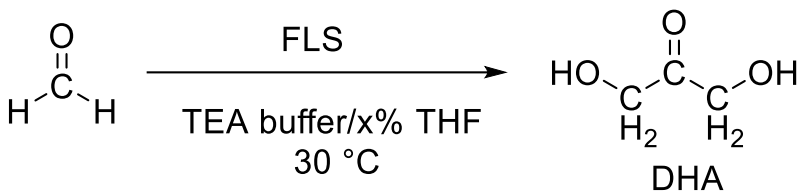

The activity of FLS was assayed in a reaction mixture $(0.8 \mathrm{~mL})$ containing FLS $(20 \mu \mathrm{M}), 10$ $\mathrm{mM}$ formaldehyde and TEA buffer (25 mM, pH 7.0) containing $1 \mathrm{mM} \mathrm{MgSO}_{4}$ and $0.1 \mathrm{mM}$ TPP. 10 or $20 \%$ THF were added when required. The samples were placed at $30{ }^{\circ} \mathrm{C}$ and shaken at $900 \mathrm{rpm}$. Aliquots of $0.1 \mathrm{~mL}$ were taken after given time. The aliquots were heated at $98{ }^{\circ} \mathrm{C}$ for 3 minutes, centrifuged for 2 minutes at $12000 \mathrm{x}$ g and the supernatant solution was analyzed by analytical HPLC. The activity of FLS in the reaction buffer is in accordance with previous results reported in the literature. ${ }^{9,10}$

Table S3. FLS-catalyzed trimerization of commercial formaldehyde into DHA with different $\%$ of THF.

\begin{tabular}{cccccccc}
\hline \multirow{2}{*}{ Conditions } & \multicolumn{7}{c}{ Yield (\%) of DHA overtime } \\
\cline { 2 - 8 } & $<\mathbf{1} \mathbf{~} \mathbf{m i n}$ & $\mathbf{1 ~ h}$ & $\mathbf{2} \mathbf{~ h}$ & $\mathbf{4} \mathbf{~ h}$ & $\mathbf{7} \mathbf{~ h}$ & $\mathbf{2 4} \mathbf{~ h}$ & $\mathbf{4 8} \mathbf{~ h}$ \\
\hline $\mathbf{0 \%}$ THF & 3 & 44 & 58 & 76 & 82 & 83 & 94 \\
$\mathbf{1 0 \%}$ THF & 1 & 46 & 67 & 83 & 84 & $>99$ & $>99$ \\
$\mathbf{2 0 \%}$ THF & 0 & 8 & 9 & 10 & 11 & 11 & 11 \\
\hline
\end{tabular}

The yields have been determined from monoplicat

Following the procedure described above, the reaction was performed in absence of FLS (in the presence of 10 or $20 \%$ THF when required) showing no consumption of formaldehyde and no generation of DHA. 


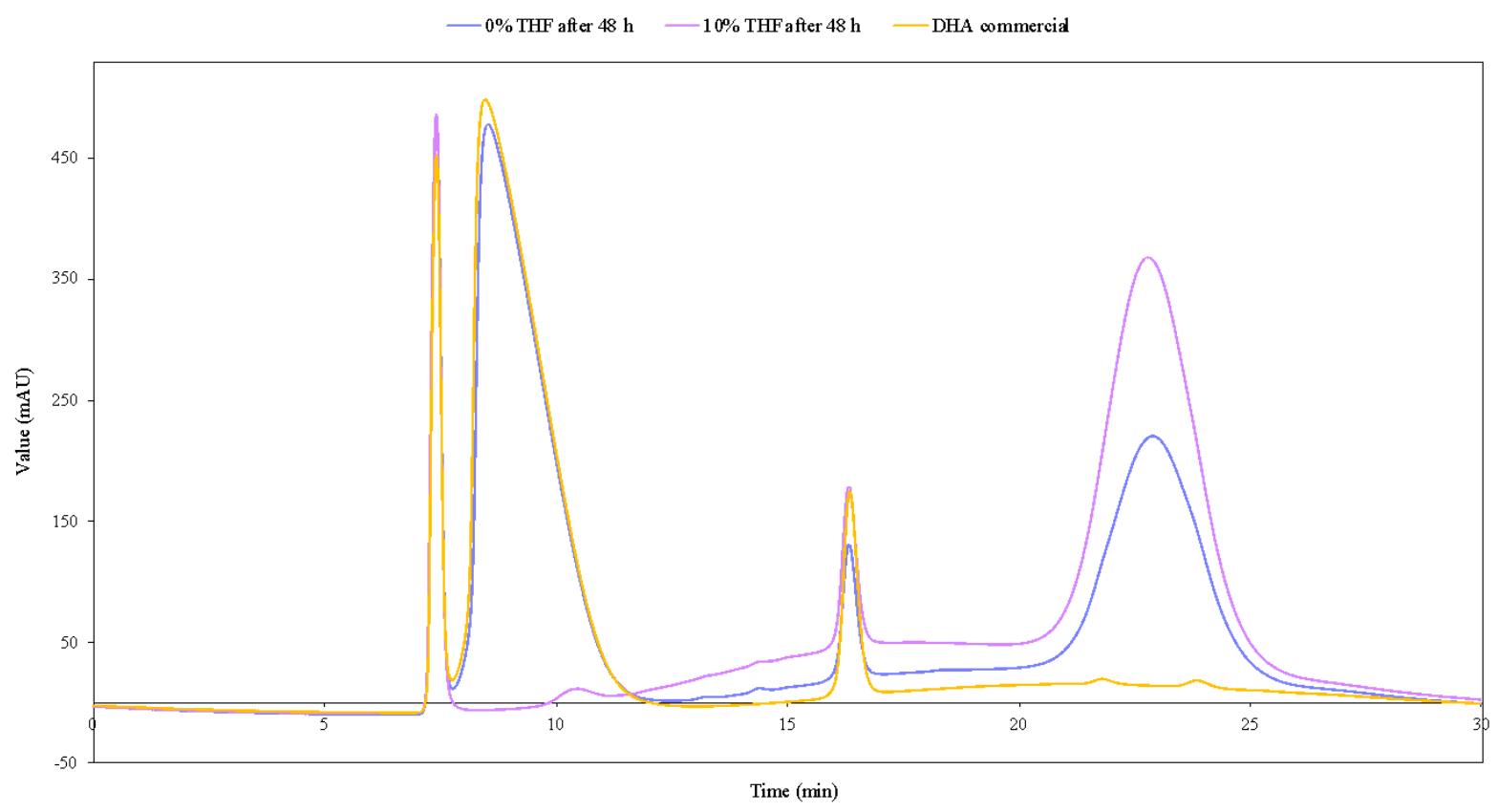

Figure S19: Chromatogram for FLS and $10 \mathrm{mM}$ commercial HCHO for Entry: 0\% THF and $10 \% \mathrm{THF}$ after $48 \mathrm{~h}$ and comparison with the peak of commercial DHA. 


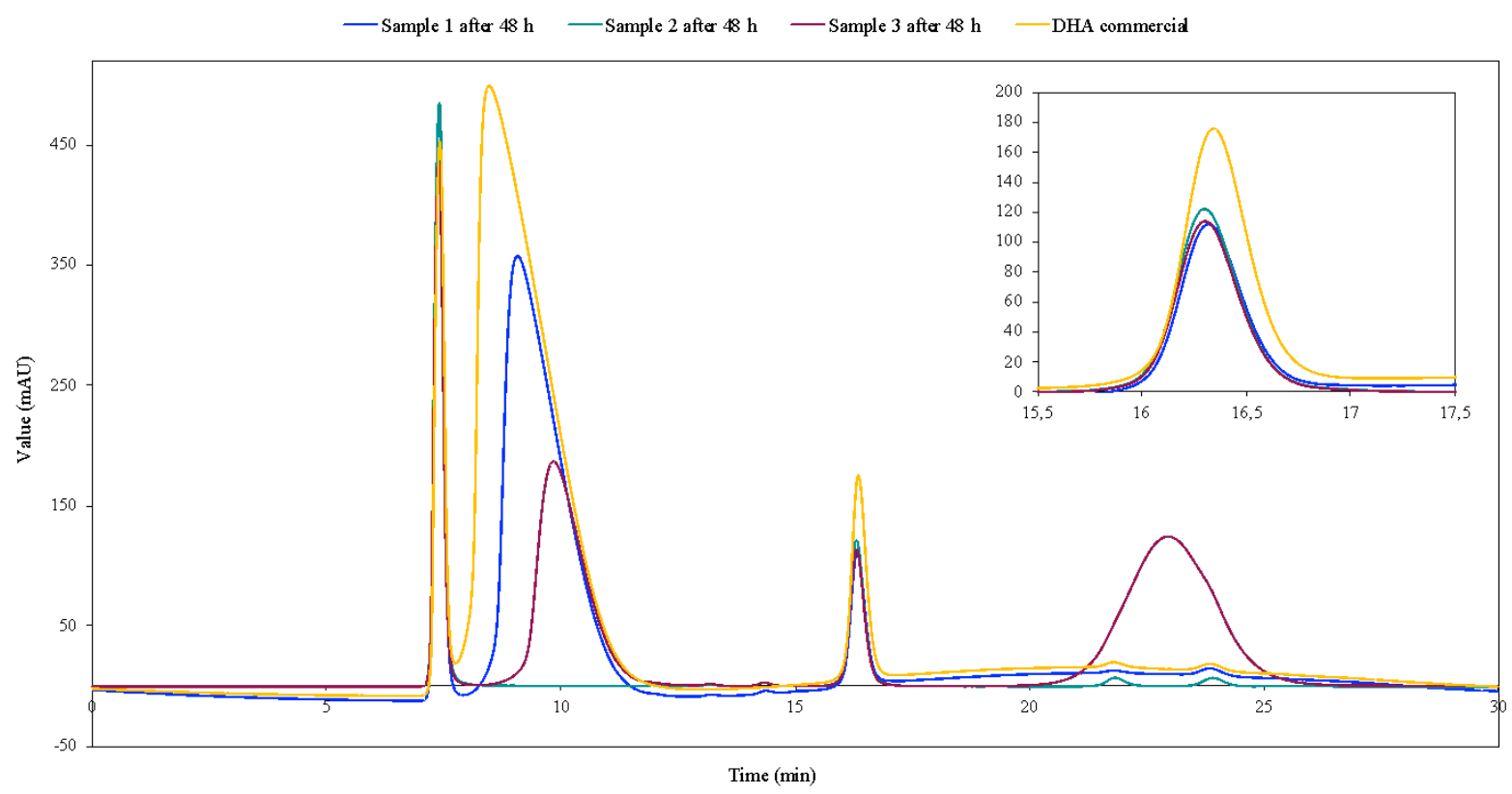

Figure S20: Chromatogram for the FLS-catalyzed formation of DHA from 1 (10 mM): 10\% THF after $48 \mathrm{~h}$ with the best yield of $86 \pm 4 \%$, and comparison with the peak of commercial DHA. 


\section{FLS-catalyzed synthesis of $3-{ }^{13} \mathrm{C}$ from $1-{ }^{13} \mathrm{C}$}

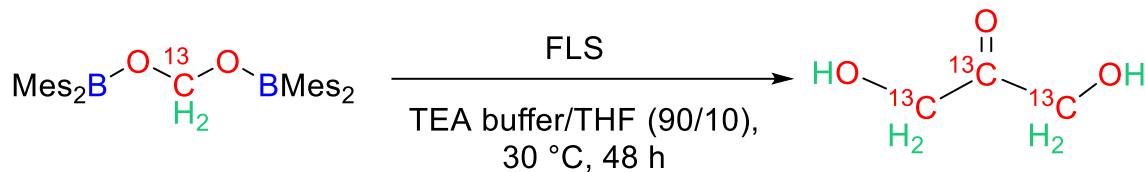

The reaction mixture was prepared in an Eppendorf tube $(1 \mathrm{ml})$ for a total volume of $0.8 \mathrm{~mL}$ : $10 \mathrm{mM} \mathbf{1 -}^{13} \mathrm{C}, 80 \mu \mathrm{L}$ of THF (10\%), TEA buffer (25 mM, pH 7.0) containing $1 \mathrm{mM} \mathrm{MgSO}_{4}$ and $0.1 \mathrm{mM}$ TPP and $20 \mu \mathrm{M}$ FLS were successively added. The sample was placed at $30{ }^{\circ} \mathrm{C}$ and shaken at $900 \mathrm{rpm}$ for 48 hours, leading to a $59 \%$ yield by HPLC. The supernatant solution was transferred to a Schlenk tube and the volatile removed by vacuum. The residues were then dissolved in $\mathrm{D}_{2} \mathrm{O}$ and analyzed by ${ }^{1} \mathrm{H}$ and ${ }^{13} \mathrm{C}$ NMR spectroscopy.

${ }^{13} \mathbf{C}\left\{{ }^{1} \mathbf{H}\right\}$ NMR $\left(\mathrm{D}_{2} \mathrm{O}, 298 \mathrm{~K}, 101 \mathrm{MHz}\right): \delta 212.1\left(\mathrm{t},{ }^{1} J_{\mathrm{C}-\mathrm{C}}=41.6 \mathrm{~Hz},{ }^{13} \mathrm{CO}\right), 64.9\left(\mathrm{~d},{ }^{1} J_{\mathrm{C}-\mathrm{C}}=41.4\right.$ $\left.\mathrm{Hz},{ }^{13} \mathrm{CH}_{2}\right) .{ }^{1} \mathbf{H}$ NMR $\left(\mathrm{D}_{2} \mathrm{O}, 298 \mathrm{~K}, 400 \mathrm{MHz}\right)$ spectrum exhibits a second order signal for the $\mathrm{CH}_{2}$. The spectrum was simulated with MestReNova spin simulation program. Based on an AA'BB'CC'D simulation and introducing a ${ }^{2} J_{\mathrm{C}-\mathrm{C}}$ of $20 \mathrm{~Hz}$ (see Fig S21): $\delta 4.42\left({ }^{1} J_{\mathrm{C}-\mathrm{H}}=143.0\right.$ $\left.\mathrm{Hz},{ }^{2} J_{\mathrm{C}-\mathrm{H}}=3.0 \mathrm{~Hz}, 2 \mathrm{H},{ }^{13} \mathrm{CH}_{2}\right)$.

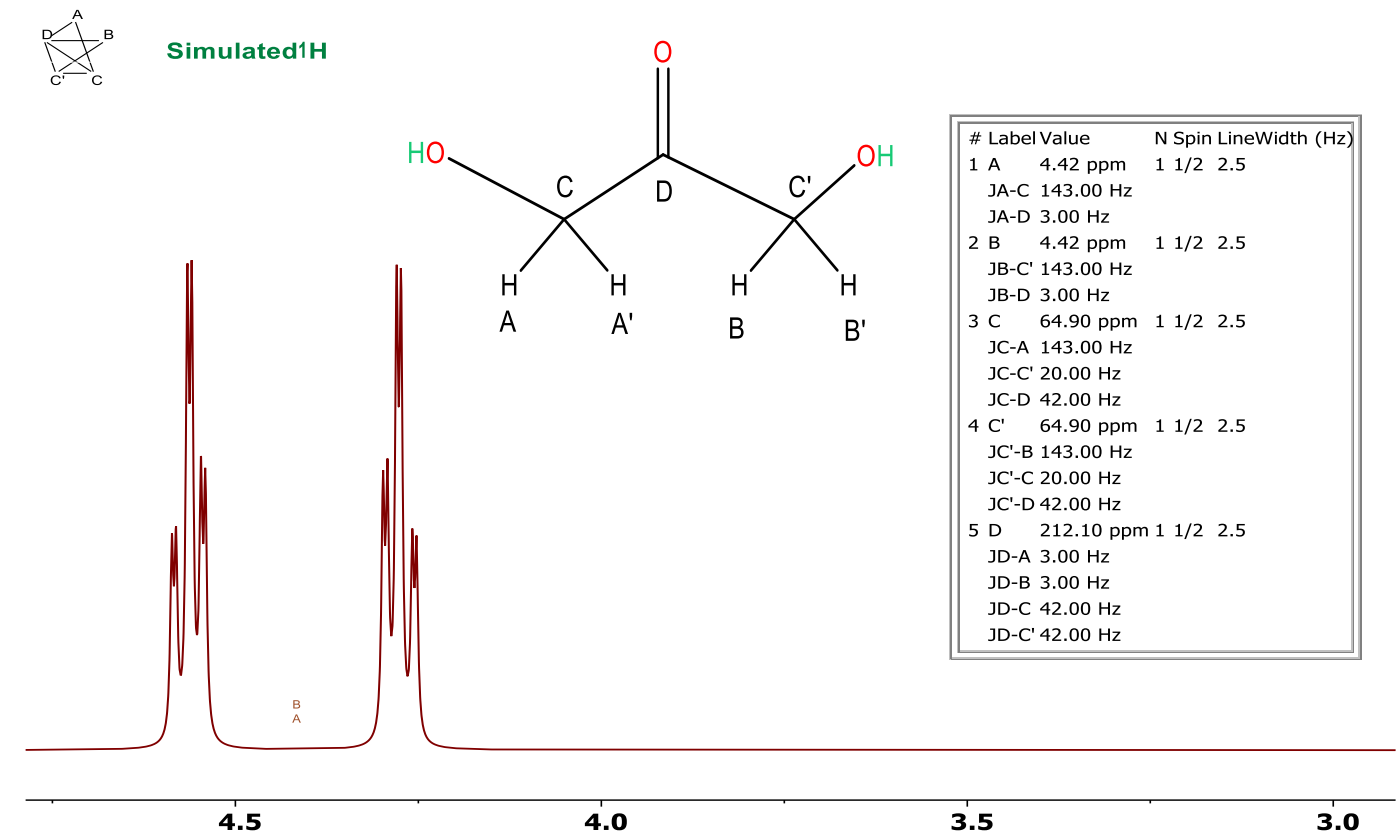

Figure S21. AA 'BB'CC'D simulation of the ${ }^{1} \mathrm{H}$ NMR signal of $\mathrm{CH}_{2}$ in compound 3-13 $\mathbf{C}$. 


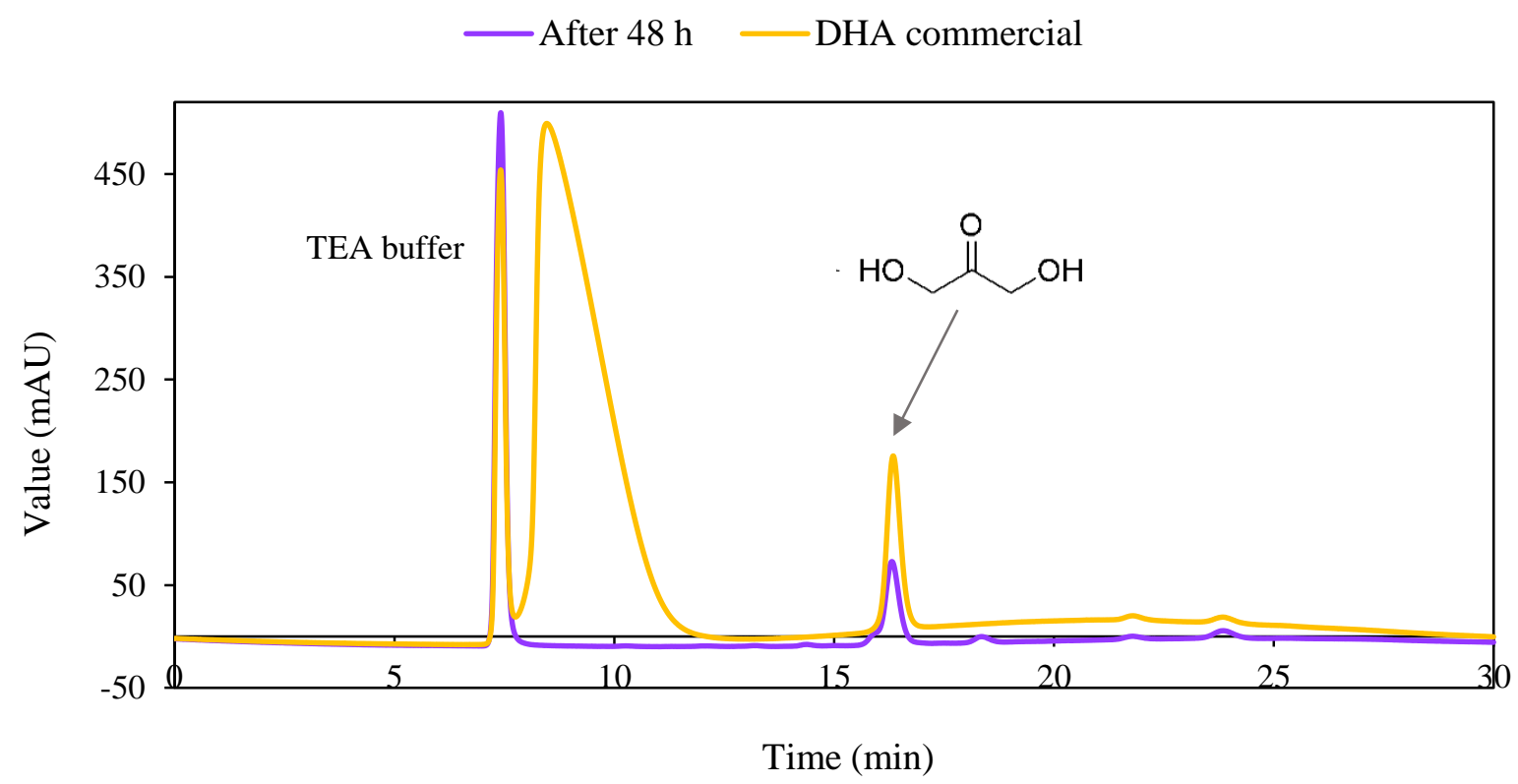

Figure S22. HPLC analysis of the FLS-catalyzed synthesis of $\mathbf{3 -}^{\mathbf{1 3}} \mathbf{C}$ from $1-{ }^{\mathbf{1 3}} \mathbf{C}$ obtained after 48 hours (purple chromatogram) and comparison with commercial DHA sample (yellow chromatogram). 


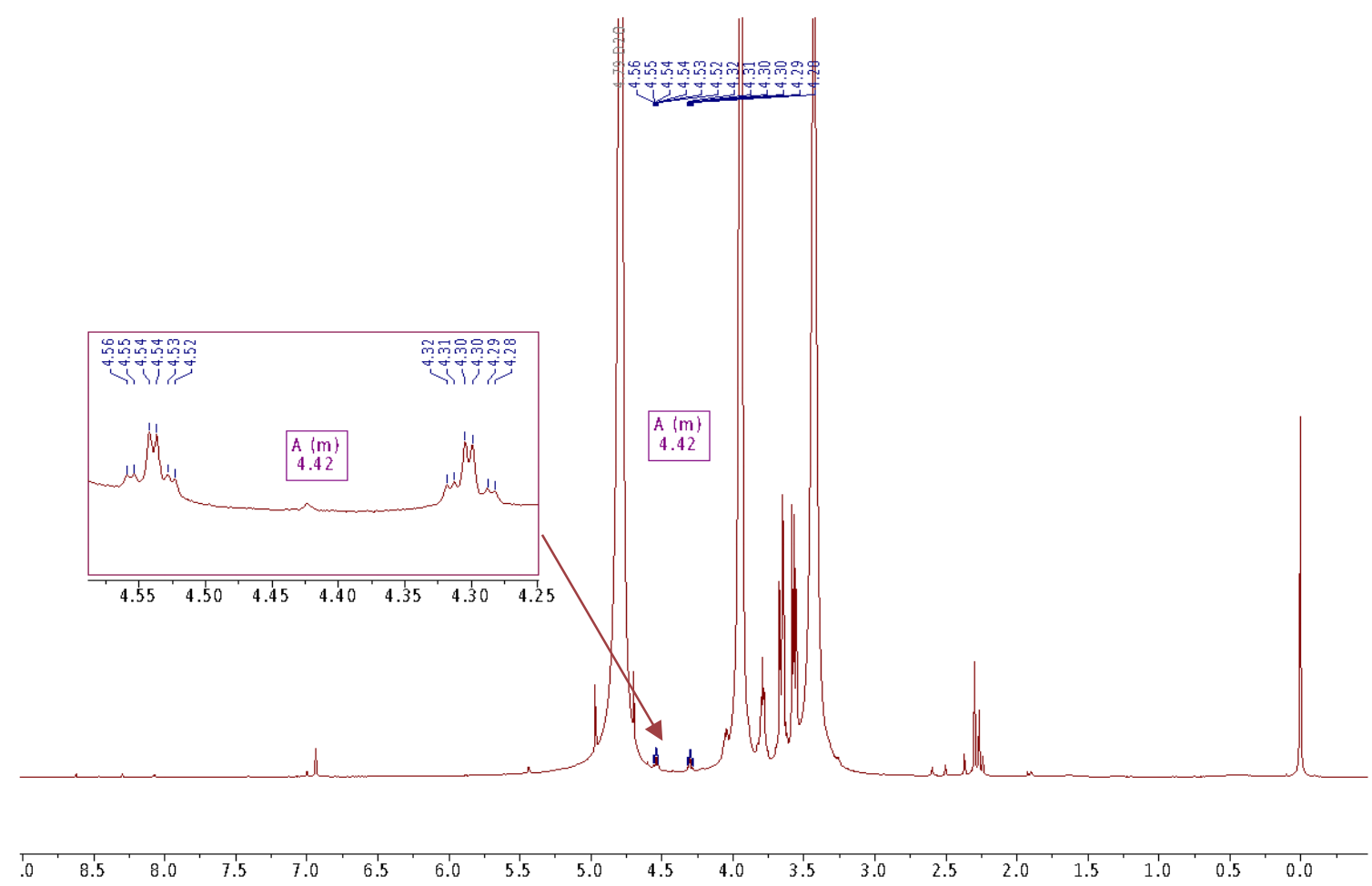

Figure S23. ${ }^{1} \mathrm{H}$ NMR spectrum of generated $\mathbf{3 -}^{\mathbf{1 3}} \mathbf{C}$ in $\mathrm{D}_{2} \mathrm{O}$ at $298 \mathrm{~K}$.

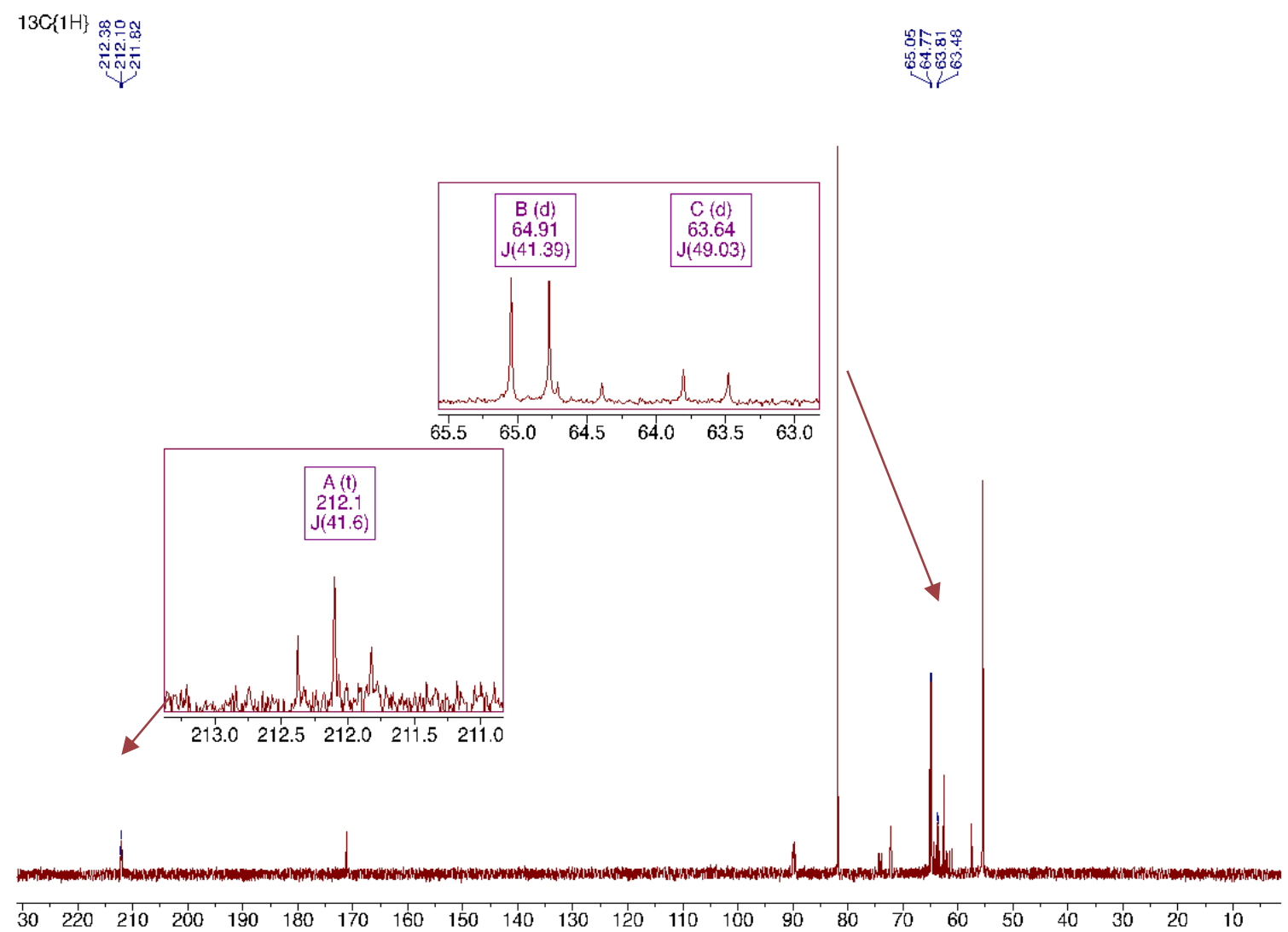

Figure S24. ${ }^{13} \mathrm{C}\left\{{ }^{1} \mathrm{H}\right\}$ NMR spectrum of generated $\mathbf{3 -}^{\mathbf{1 3}} \mathbf{C}$ in $\mathrm{D}_{2} \mathrm{O}$ at $298 \mathrm{~K}$. 


\section{FLS-catalyzed synthesis of 3 from $\mathrm{CO}_{2}$ in a one-pot process}

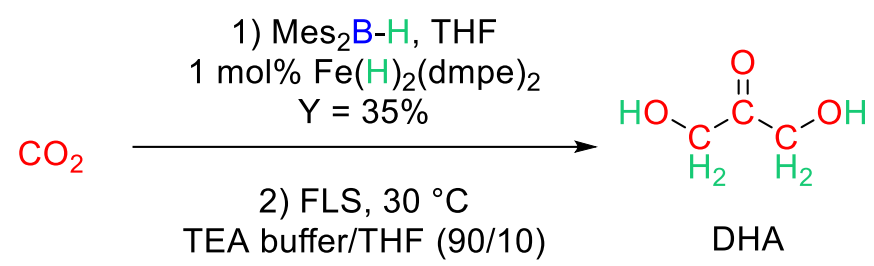

A pressured NMR tube was charged with $\mathrm{Mes}_{2} \mathrm{BH}(53 \mathrm{mg}, 0.21 \mathrm{mmol}), \mathrm{Fe}(\mathrm{H})_{2}(\mathrm{dmpe})_{2}(0.8$ $\mathrm{mg}, 0.0021 \mathrm{mmol}, 1 \mathrm{~mol} \%)$ and THF- $d_{8}(c a .0 .8 \mathrm{~mL})$. Part of Mes ${ }_{2} \mathrm{BH}$ was insoluble in THF$d_{8}$. The mixture was degassed and placed under a dynamic pressure of 1 atmosphere of $\mathrm{CO}_{2}$ for 3 minutes. The mixture readily turned orange upon introduction of ${ }^{13} \mathrm{CO}_{2}$. The tube was then closed and placed in a $25{ }^{\circ} \mathrm{C}$ for 50 minutes. After filtration, an aliquot of the pale orange solution obtained was taken to determine the yield of 1 by ${ }^{1} \mathrm{H}$ NMR spectroscopy by integration relative to hexamethylbenzene as an internal standard. 1 was obtained in $35 \%$ in situ yield (20.1 $\mathrm{mg}, 0.037 \mathrm{mmol}$ ). To $3 \times 80 \mu \mathrm{L}$ of $\mathbf{1}$ in solution in THF (10\% THF and $4.7 \mathrm{mM}$ of $\mathbf{1}$ for a final volume of $0.8 \mathrm{~mL})$ was added FLS $(20 \mu \mathrm{M})$ and TEA buffer $(25 \mathrm{mM}$, pH 7.0) containing $1 \mathrm{mM}$ $\mathrm{MgSO}_{4}$ and $0.1 \mathrm{mM}$ TPP. The samples were placed at $30{ }^{\circ} \mathrm{C}$ and shaken at $900 \mathrm{rpm}$. Aliquots of $0.1 \mathrm{~mL}$ were taken after $0,1,2,4,7,24$ and 48 hours. The aliquots were heated at $98{ }^{\circ} \mathrm{C}$ for 3 minutes, centrifuged for 2 minutes at $12000 \mathrm{x}$ g and the supernatant solution was analyzed by analytical HPLC. The yields of DHA obtained at the different time points are reported in Table S4.

Table S4. Yields of the FLS-catalyzed synthesis of DHA from $\mathrm{CO}_{2}$.

\begin{tabular}{cccccccc}
\hline \multirow{2}{*}{ Condition } & \multicolumn{7}{c}{ DHA yield (\%) } \\
\cline { 2 - 8 } & $<\mathbf{1} \mathbf{m i n}$ & $\mathbf{1 ~ h}$ & $\mathbf{2} \mathbf{h}$ & $\mathbf{4} \mathbf{h}$ & $\mathbf{7} \mathbf{h}$ & $\mathbf{2 4} \mathbf{~ h}$ & $\mathbf{4 8} \mathbf{~ h}$ \\
\hline $\mathbf{1 0 \%}$ THF & $23 \pm 1$ & $24 \pm 1$ & $25 \pm 1$ & $27 \pm 1$ & $30 \pm 6$ & $31 \pm 7$ & $26 \pm 4$ \\
\hline
\end{tabular}

${ }^{a}$ The experiments were performed as triplicate. The values provided correspond to the mean of three values obtained with the corresponding error. 


\section{FSA A129S-catalyzed synthesis of L-erythrulose from commercial DHA and formaldehyde}

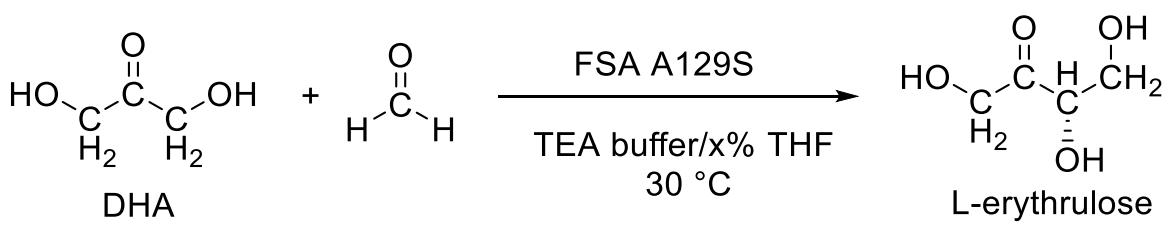

The activity of FSA A129S was probed in a reaction mixture $(0.8 \mathrm{~mL})$ containing FSA A129S $(20 \mu \mathrm{M}), 10 \mathrm{mM}$ formaldehyde, $10 \mathrm{mM}$ DHA and TEA buffer $(25 \mathrm{mM}, \mathrm{pH} 7.0)$ containing 1 $\mathrm{mM} \mathrm{MgSO}_{4}$ and $0.1 \mathrm{mM}$ TPP. 10 or $20 \%$ THF were added when required. The samples were placed at $30{ }^{\circ} \mathrm{C}$ and shaken at $900 \mathrm{rpm}$. Aliquots of $0.1 \mathrm{~mL}$ were taken after given time. The aliquots were heated at $98{ }^{\circ} \mathrm{C}$ for 3 minutes, centrifuged for 2 minutes at $12000 \mathrm{x} \mathrm{g}$ and the supernatant solution was analyzed by analytical HPLC. The activity of FSA A129S in the reaction buffer is in accordance with previous results reported in the literature. ${ }^{11}$

Table S5. Yields of FSA A129S-catalyzed aldol condensation reaction between commercial formaldehyde and DHA into L-erythrulose.

\begin{tabular}{cccc}
\hline \multirow{2}{*}{ Conditions } & \multicolumn{3}{c}{ Yield (\%) of L-erythrulose overtime } \\
\cline { 2 - 4 } & $<\mathbf{1 ~} \mathbf{~ m i n}$ & $\mathbf{1}$ & $\mathbf{2 ~ h}$ \\
\hline 0\% $\mathbf{~ T H F}$ & 18 & 87 & 95 \\
$\mathbf{1 0 \%}$ THF & 17 & 95 & 99 \\
$\mathbf{2 0 \%}$ THF & 9 & 92 & 98 \\
\hline
\end{tabular}

Following the procedure described above, the reaction was performed in absence of one of the two substrates (i.e. formaldehyde or DHA) showing no consumption of the substrate and no formation of product. Finally, the reaction was performed in absence of FSA A129S (in the presence of 10 or $20 \%$ THF when required) showing no consumption of formaldehyde and DHA and no generation of L-erythrulose. 


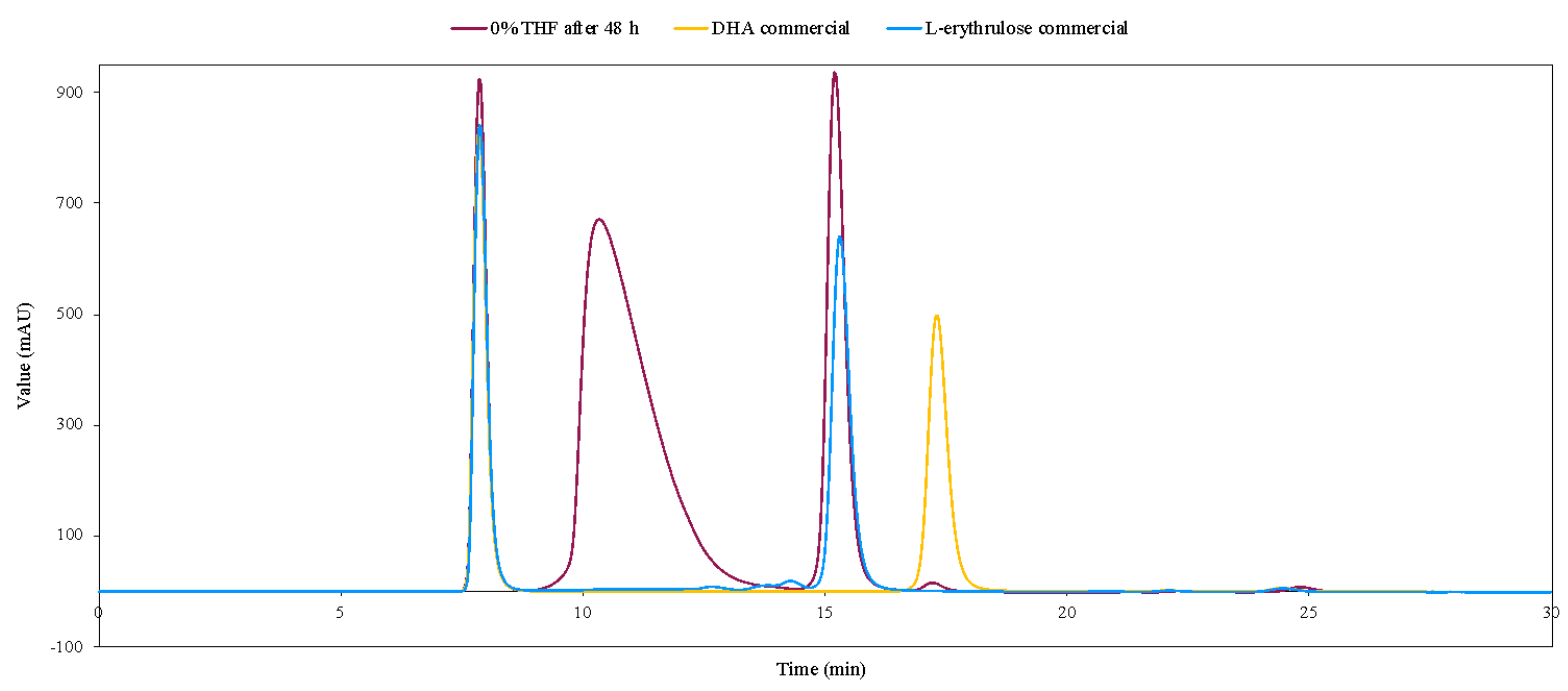

Figure S25: Chromatogram for the FSA A129S-catalyzed aldol reaction between commercial HCHO and DHA (10 mM each): 0\% THF after $48 \mathrm{~h}$ (purple chromatogram) and comparison with the peak of commercial DHA and L-erythrulose (yellow and blue chromatograms, respectively). 


\section{FLS/FSA A129S cascade reaction with commercial HCHO}

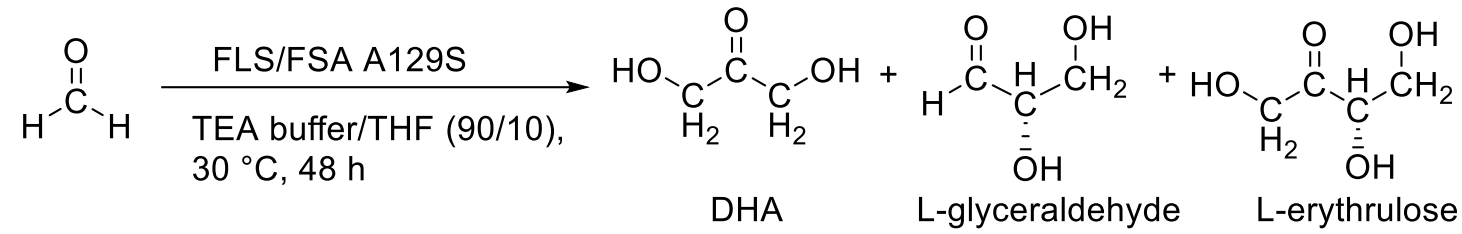

Prior to the cascade reaction (procedure a or $\mathbf{b}$, below), each step of the cascade was performed independently to control the activity of FLS and FSA A129S. The control experiments were performed using $10 \mathrm{mM}$ of substrates (i.e. HCHO and/or DHA), $20 \mu \mathrm{M}$ of enzyme (i.e. FSA A129S or FLS), freshly prepared TEA buffer (25 mM, pH 7.0) containing $1 \mathrm{mM} \mathrm{MgSO}_{4}$ and $0.1 \mathrm{mM}$ TPP and 10 or $20 \%$ THF when required.

Procedure a: The cascade reaction was performed in a reaction mixture $(0.8 \mathrm{~mL})$ containing FLS and FSA A129S (20 $\mu \mathrm{M}$ each), $10 \mathrm{mM}$ formaldehyde and TEA buffer (25 mM, pH 7.0) containing $1 \mathrm{mM} \mathrm{MgSO}_{4}$ and $0.1 \mathrm{mM}$ TPP. 10 or $20 \%$ THF were added when required. The samples were placed at $30{ }^{\circ} \mathrm{C}$ and shaken at $900 \mathrm{rpm}$. Aliquots of $0.1 \mathrm{~mL}$ was taken after 48 hours. The aliquots were heated at $98^{\circ} \mathrm{C}$ for 3 minutes, centrifuged for 2 minutes at $12000 \mathrm{x} \mathrm{g}$ and the supernatant solution was analyzed by analytical HPLC.

Procedure b: The cascade reaction was run in two steps starting with a reaction mixture $(0.8$ $\mathrm{mL})$ containing FLS $(20 \mu \mathrm{M}), 10 \mathrm{mM}$ formaldehyde and TEA buffer (25 mM, pH 7.0) containing $1 \mathrm{mM} \mathrm{MgSO}_{4}$ and $0.1 \mathrm{mM}$ TPP. 10\% THF was added when required. The samples were placed at $30^{\circ} \mathrm{C}$ shaken at $900 \mathrm{rpm}$ for 24 hours. An aliquot of $0.1 \mathrm{~mL}$ was taken to control the yield in DHA. Then, FSA A129S $(20 \mu \mathrm{M})$ and formaldehyde $(2.8 \mathrm{mM})$ were added into the reaction mixture and left for another 24 hours. The aliquots of $0.1 \mathrm{~mL}$ were heated at $98{ }^{\circ} \mathrm{C}$ for 3 minutes, centrifuged for 2 minutes at $12000 \mathrm{x}$ g and the supernatant solution was analyzed by analytical HPLC. All results obtained are combined in Table S6 and are in accordance with previous results reported in the literature. ${ }^{12}$ 
Table S6. Yields obtained for the FLS/FSA A129S cascade reaction using commercial formaldehyde after 48 hours.

\begin{tabular}{cccc}
\hline Conditions & $\begin{array}{c}\text { L-erythrulose } \\
\text { Yield (\%) }\end{array}$ & $\begin{array}{c}\text { L-glyceraldehyde } \\
\text { Yield (\%) }\end{array}$ & $\begin{array}{c}\text { Dihydroxyacetone } \\
\text { Yield (\%) }\end{array}$ \\
\hline $\mathbf{0 \%} \mathbf{T H F}^{a}$ & 80 & 17 & 3 \\
$\mathbf{1 0 \%} \mathbf{T H F}^{a}$ & 69 & 24 & 7 \\
$\mathbf{2 0 \%} \mathbf{T H F}^{a}$ & 22 & 4 & $<1$ \\
\hline $\mathbf{0 \%} \mathbf{T H F}^{b}$ & 99 & - & $<1$ \\
$\mathbf{1 0 \%} \mathbf{T H F}^{b}$ & 99 & - & $<1$ \\
\hline
\end{tabular}

${ }^{a}$ procedure $\mathrm{a},{ }^{b}$ procedure $\mathrm{b}$

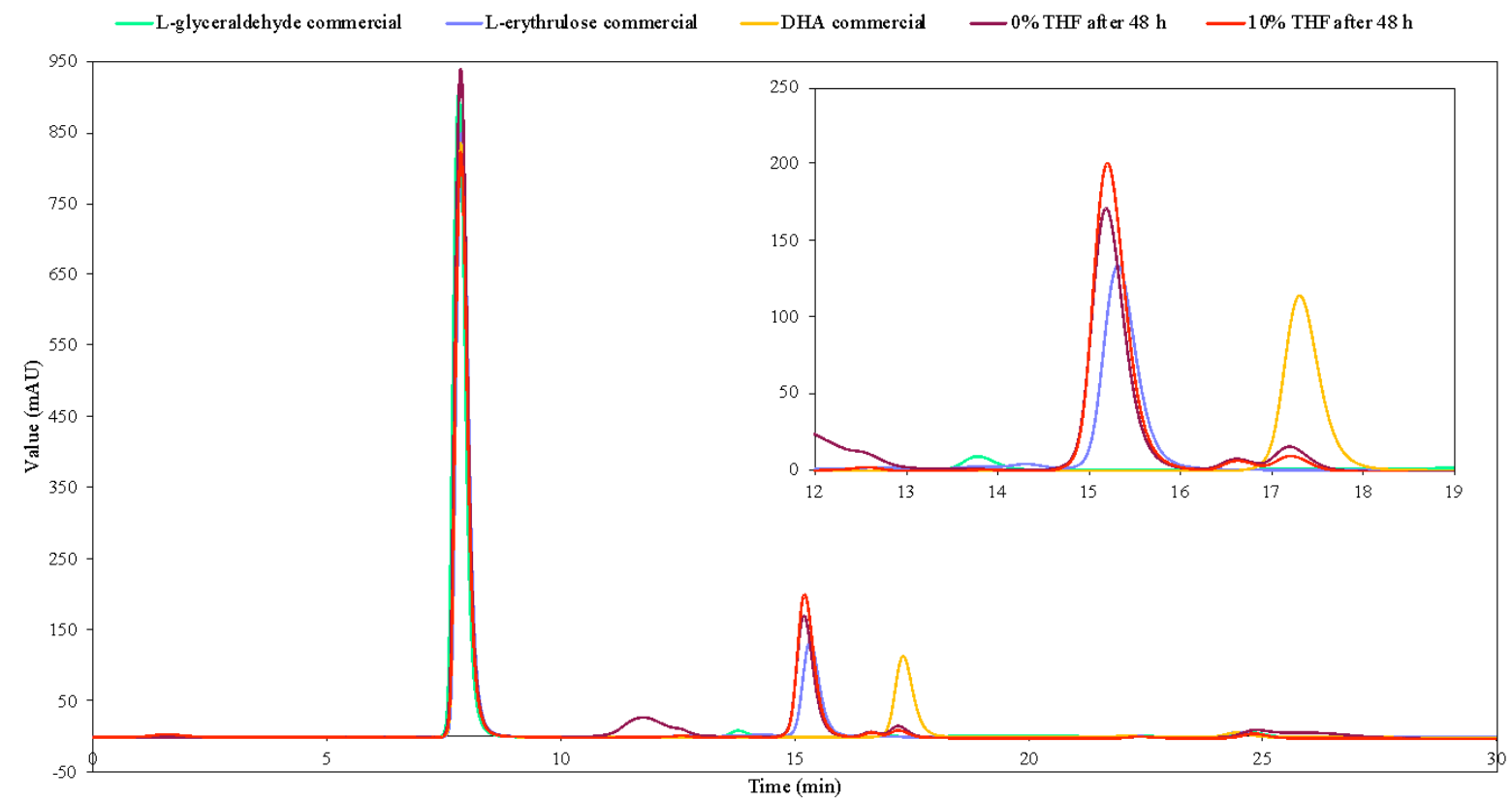

Figure S26. Chromatogram for the sequential FLS/FSA A129S cascade reaction (procedure b), with $10 \mathrm{mM} \mathrm{HCHO}$ for 0 and $10 \%$ THF after $48 \mathrm{~h}$ (purple and red chromatograms, respectively) and comparison with the peak of commercial DHA, L-glyceraldehyde and L-erythrulose (yellow, green and blue chromatograms, respectively). 


\section{FSA A129S-catalyzed synthesis of L-erythrulose from commercial DHA and 1}
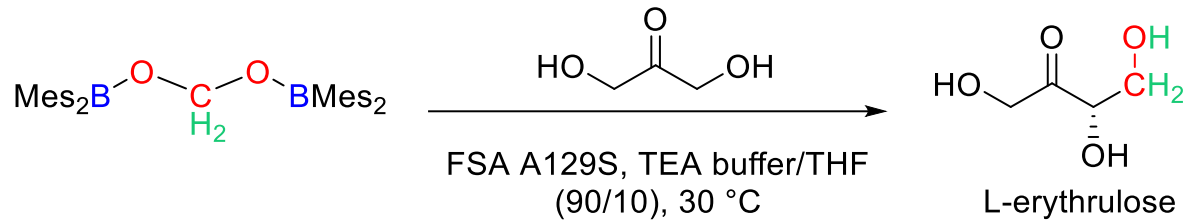

The reactions were performed in a reaction mixture $(0.8 \mathrm{~mL})$ containing FSA A129S $(20 \mu \mathrm{M})$, $10 \mathrm{mM} 1$ and TEA buffer ( $25 \mathrm{mM}, \mathrm{pH} 7.0$ ) containing $1 \mathrm{mM} \mathrm{MgSO}_{4}$ and $0.1 \mathrm{mM}$ TPP. 10 and $20 \%$ THF were added when required. The order of addition of the reaction components were the following: (i) 1, (ii) THF, (iii) TEA buffer and (iv) FSA A129S. The samples were placed at $30{ }^{\circ} \mathrm{C}$ and $900 \mathrm{rpm}$. Aliquots of $0.1 \mathrm{~mL}$ were taken after $0,1,2,4,7,24$ and 48 hours. The aliquots were heated at $98{ }^{\circ} \mathrm{C}$ for 3 minutes, centrifuged for 2 minutes at $12000 \mathrm{x} \mathrm{g}$ and the supernatant solution was analyzed by analytical HPLC. The results obtained are reported in Table S7 and the HPLC chromatogram obtained after $48 \mathrm{~h}$ compared to a commercial Lerythrulose sample is depicted in Figure S27.

Table S7. Conditions screening for FSA A129S-catalyzed synthesis of L-erythrulose from DHA and 1

\begin{tabular}{lccccccc}
\hline \multirow{2}{*}{ Conditions } & \multicolumn{7}{c}{ L-erythrulose yield (\%) } \\
\cline { 2 - 8 } & $\mathbf{0 ~ h}$ & $\mathbf{1 ~ h}$ & $\mathbf{2} \mathbf{h}$ & $\mathbf{4} \mathbf{h}$ & $\mathbf{7} \mathbf{~ h}$ & $\mathbf{2 4} \mathbf{~ h}$ & $\mathbf{4 8} \mathbf{~ h}$ \\
\cline { 2 - 7 } $\mathbf{1 0 \%} \mathbf{~ T H F}$ & 2 & 18 & 19 & $23 \pm 1$ & $28 \pm 5$ & $34 \pm 2$ & $53 \pm 3$ \\
$\mathbf{2 0 \%} \mathbf{~ T H F}$ & 0 & $17 \pm 1$ & $22 \pm 1$ & $28 \pm 1$ & $31 \pm 1$ & $39 \pm 1$ & $40 \pm 2$ \\
\hline
\end{tabular}

Each experiment was performed as triplicate. The values provided correspond to the mean of the three values obtained with the corresponding error. 


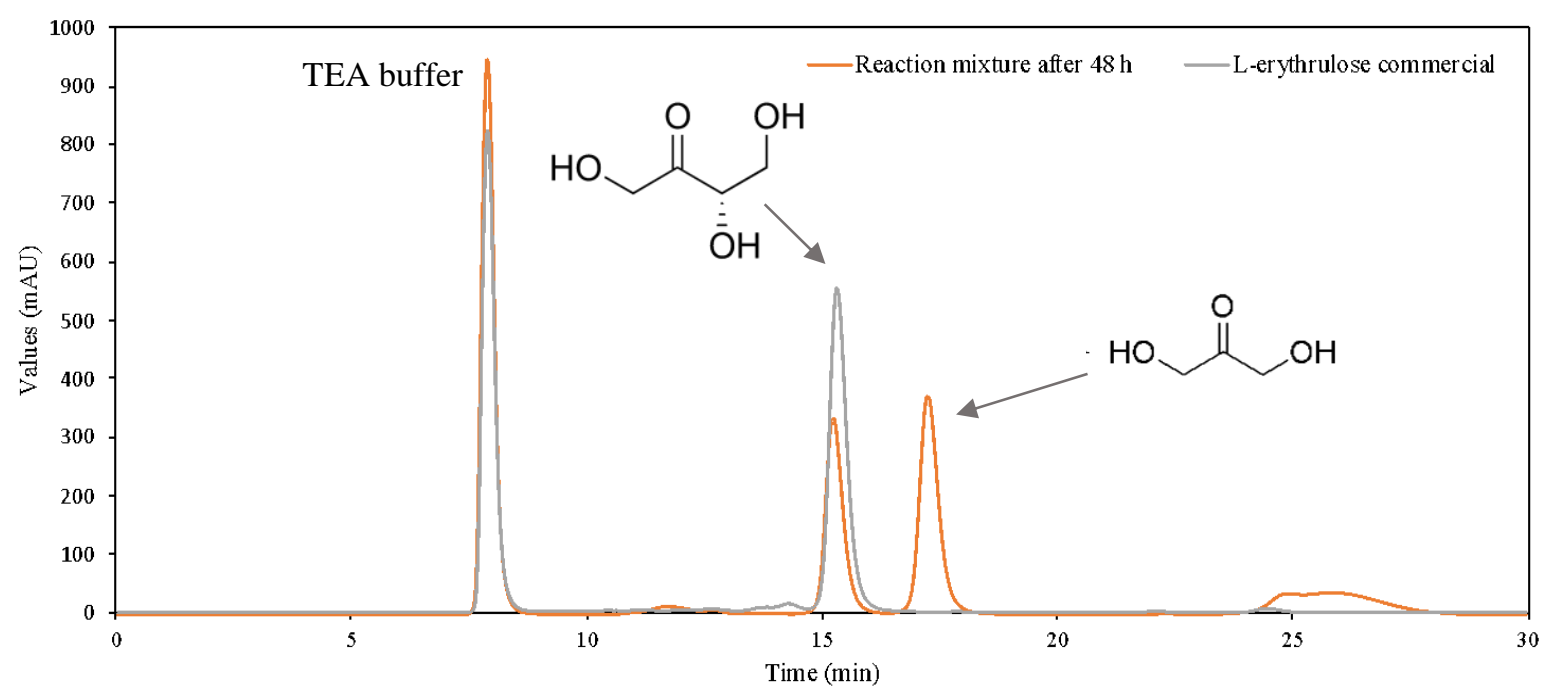

Figure S27. HPLC analysis of the FSA A129S-catalyzed synthesis of L-erythrulose from commercial DHA and 1 in the reaction mixture containing 10\% THF obtained after 48 hours (orange chromatogram) and commercial L-erythrulose sample (grey chromatogram). 


\section{Characterization of isolated $4-{ }^{13} \mathrm{C}$}

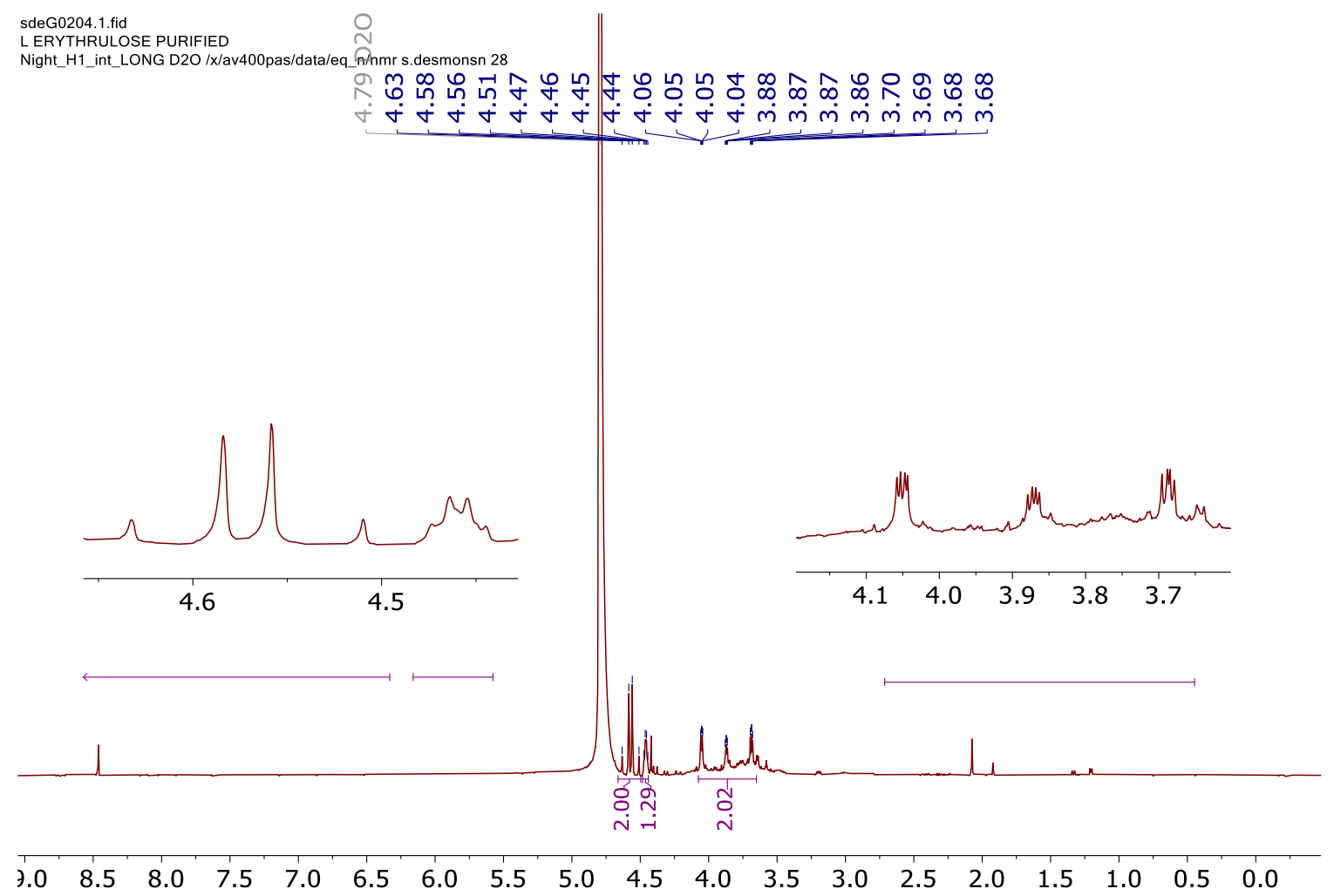

Figure S28. ${ }^{1} \mathrm{H}$ NMR spectrum of generated $\mathbf{4 -}^{\mathbf{1 3}} \mathbf{C}$ in $\mathrm{D}_{2} \mathrm{O}$ at $298 \mathrm{~K}$.

sdeG0204.3.fid

Night_C13_DECOUPLE_H1_SHORT D2O/x/av400pas/data/eq_n/nmr s.desmonsn 28

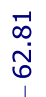

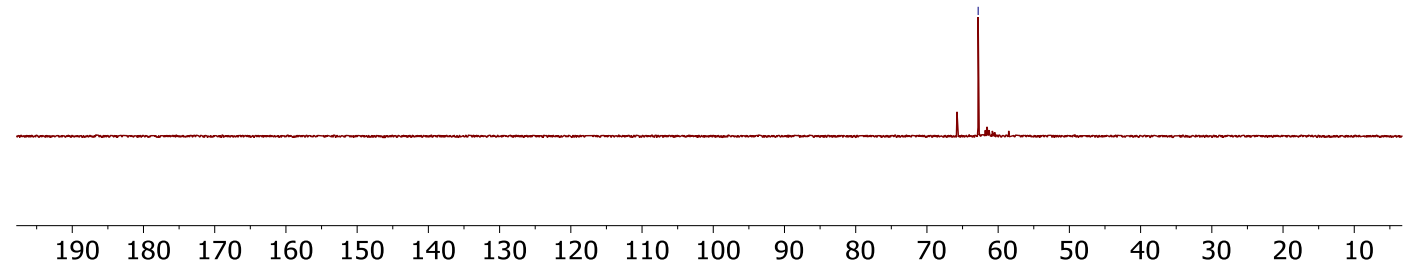

Figure S29. ${ }^{13} \mathrm{C}\left\{{ }^{1} \mathrm{H}\right\}$ NMR spectrum of generated ${ }^{4-{ }^{13}} \mathbf{C}$ in $\mathrm{D}_{2} \mathrm{O}$ (32 scans) at $298 \mathrm{~K}$. 


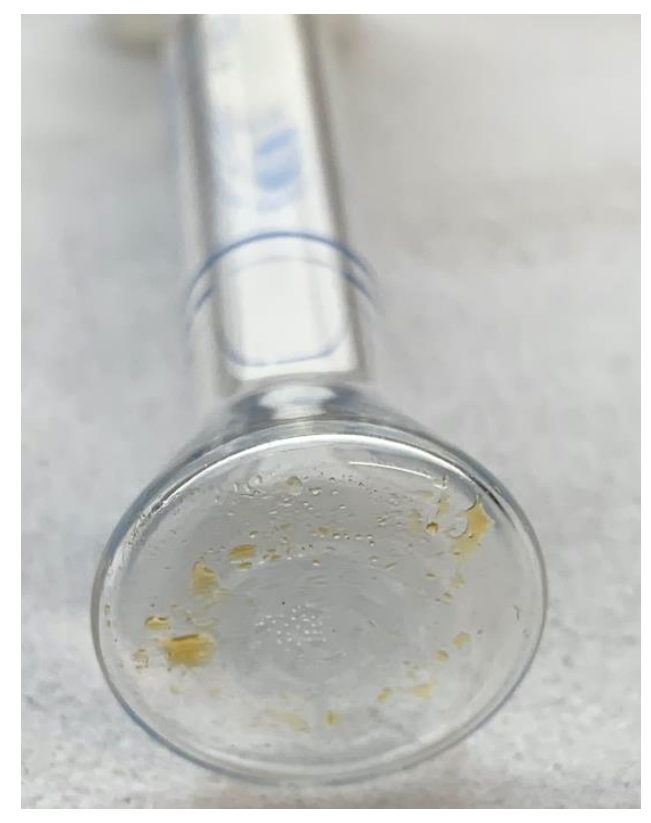

Figure S30. Picture of isolated $\mathbf{4 -}^{\mathbf{1 3}} \mathbf{C}$ synthesized from FSA A129S-catalyzed aldol reaction between $\mathbf{1 -}^{13} \mathrm{C}$ and commercial dihydroxyacetone.

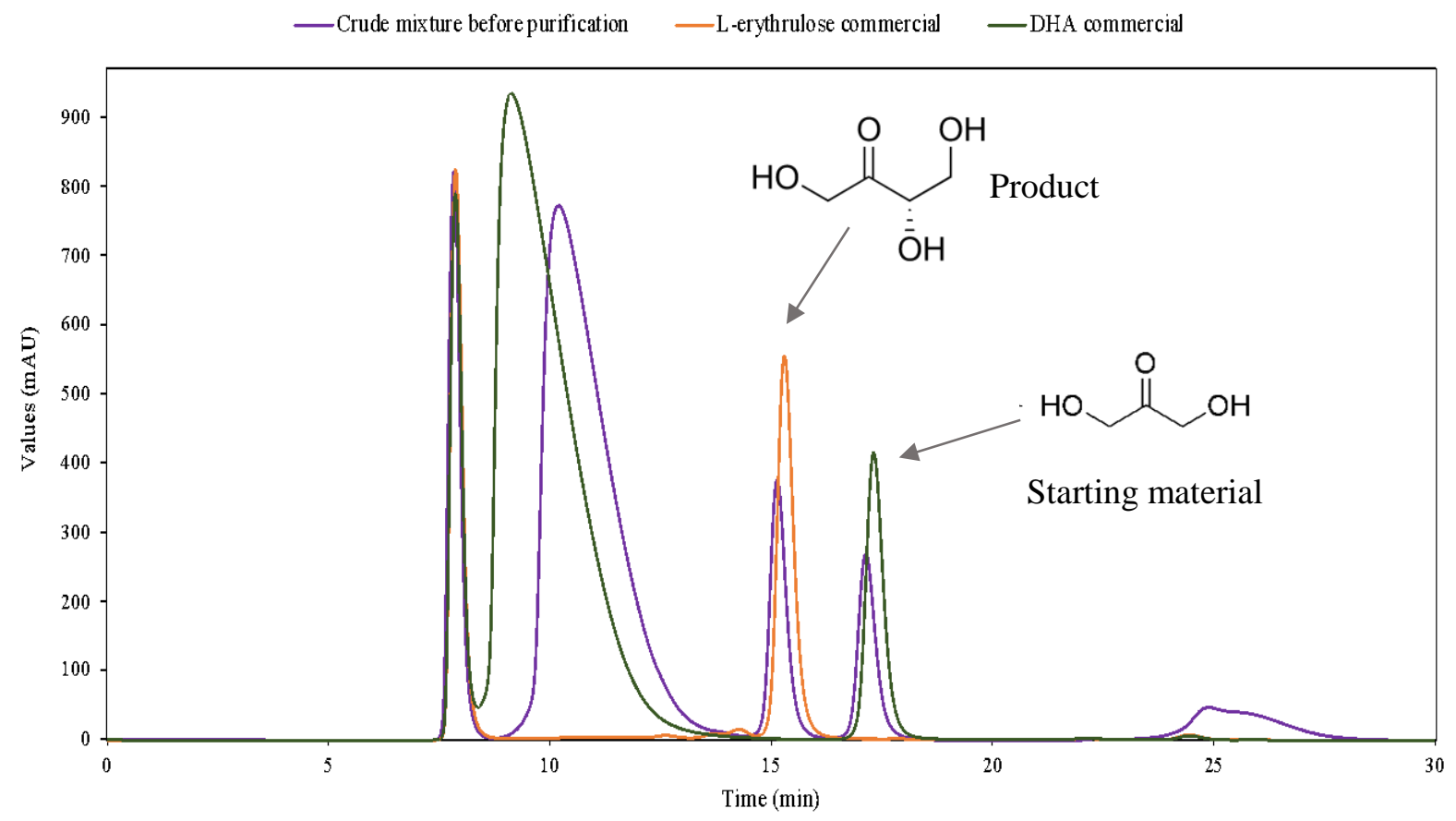

Figure S31. HPLC analysis of the crude mixture before purification (purple chromatogram) and comparison with commercial L-erythrulose (orange chromatogram) and DHA (green chromatogram) samples. 


\section{Synthesis of L-erythrulose from FLS/FSA A129S cascade reaction with 1}

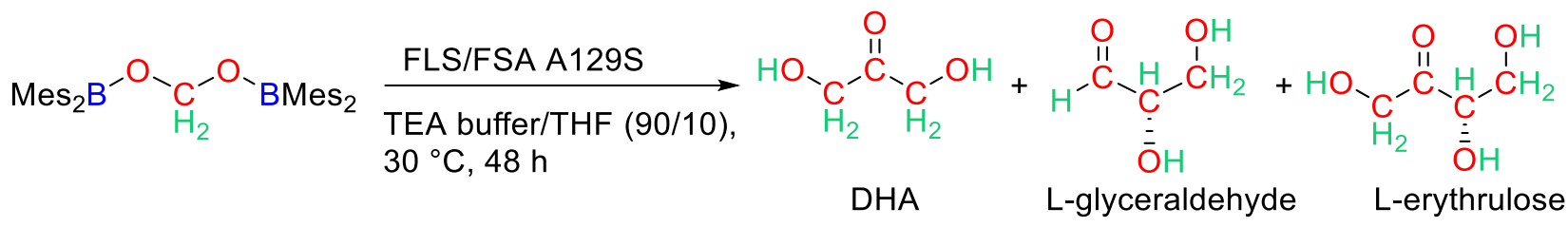

Table S8. FLS/FSA A129S cascade reaction for the conversion of 1 into 4.

\begin{tabular}{|c|c|c|c|}
\hline Time (h) & $\begin{array}{c}\text { L-erythrulose } \\
\text { Yield }(\%)^{\mathrm{a}}\end{array}$ & $\begin{array}{c}\text { L-glyceraldehyde } \\
\text { Yield }(\%)^{\mathrm{a}}\end{array}$ & $\begin{array}{c}\text { Dihydroxyacetone } \\
\text { Yield }(\%)^{\mathrm{a}}\end{array}$ \\
\hline O & 0 & 0 & 0 \\
\hline 1 & 1 & $3 \pm 1$ & 0 \\
\hline 2 & $2 \pm 1$ & $5 \pm 1$ & 1 \\
\hline 4 & $3 \pm 1$ & $8 \pm 1$ & 1 \\
\hline 7 & $4 \pm 1$ & $9 \pm 1$ & $3 \pm 1$ \\
\hline 24 & $15 \pm 2$ & $15 \pm 1$ & $14 \pm 2$ \\
\hline 48 & $35 \pm 1$ & $15 \pm 3$ & $13 \pm 2$ \\
\hline
\end{tabular}

${ }^{a}$ The experiments were performed in triplicate. The values provided correspond to the mean of the three values obtained with the corresponding error.

Following the procedure described above, the reaction was performed in triplicate in the presence of $20 \%$ THF. However, only a small amount of product was generated in the reaction mixture.

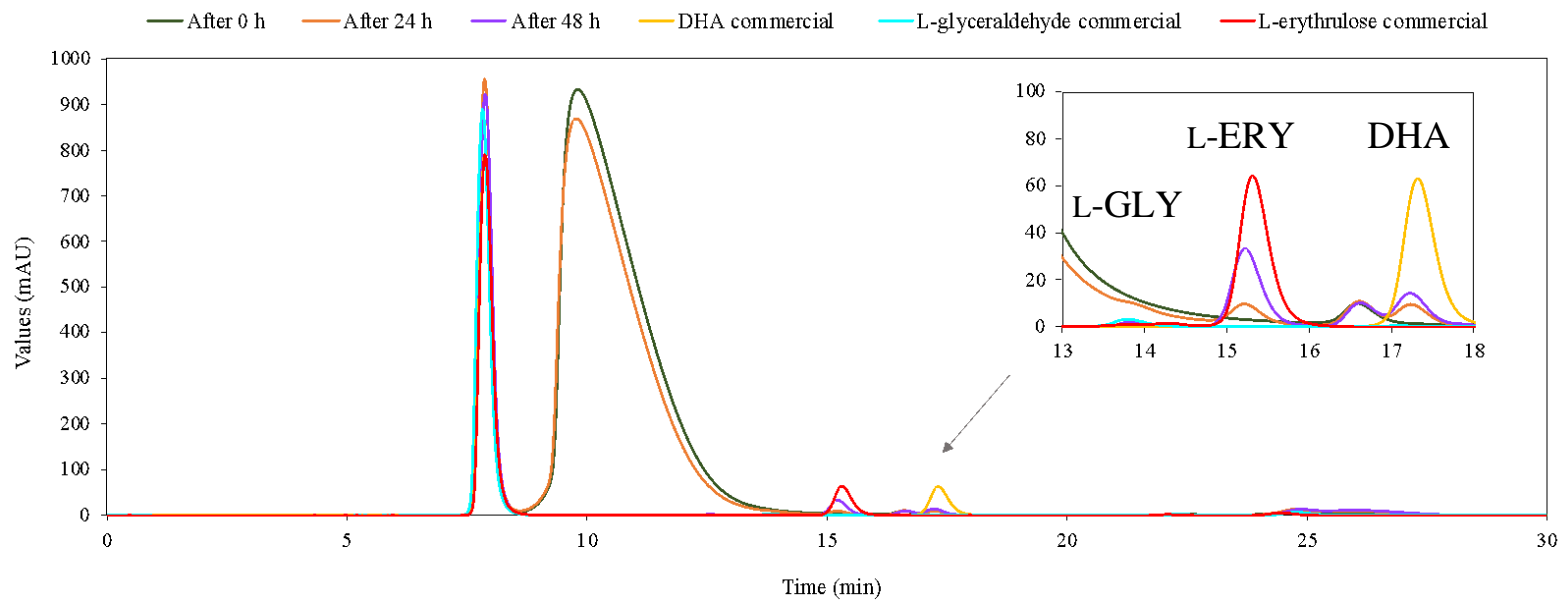

Figure S32. HPLC analysis of the FLS/FSA A129S cascade reaction for the conversion of 1 into 4, reaction mixture after $0 \mathrm{~h}$ (green chromatogram), $24 \mathrm{~h}$ (orange chromatogram) and $48 \mathrm{~h}$ 
(purple chromatogram) and comparison with commercial DHA (yellow chromatogram), Lglyceraldehyde (blue chromatogram) and L-erythrulose (red chromatogram) samples. 


\section{Calibration curves}

Commercial dihydroxyacetone (DHA), formaldehyde (37 wt \%), L-glyceraldehyde and Lerythrulose were used. New calibration curves were always constructed (usually 1 day before) for each session of enzymatic catalysis. At least 6 different concentrations of standards, in the same solvent conditions, thus including THF when applicable, were used for the construction of each calibration curve. The standards were treated as the reaction mixture: heated at $98{ }^{\circ} \mathrm{C}$ for 3 minutes, centrifuged for 2 minutes at $12000 \mathrm{x}$ g and the solution analyzed by analytical HPLC in order to mimic the real conditions at best.

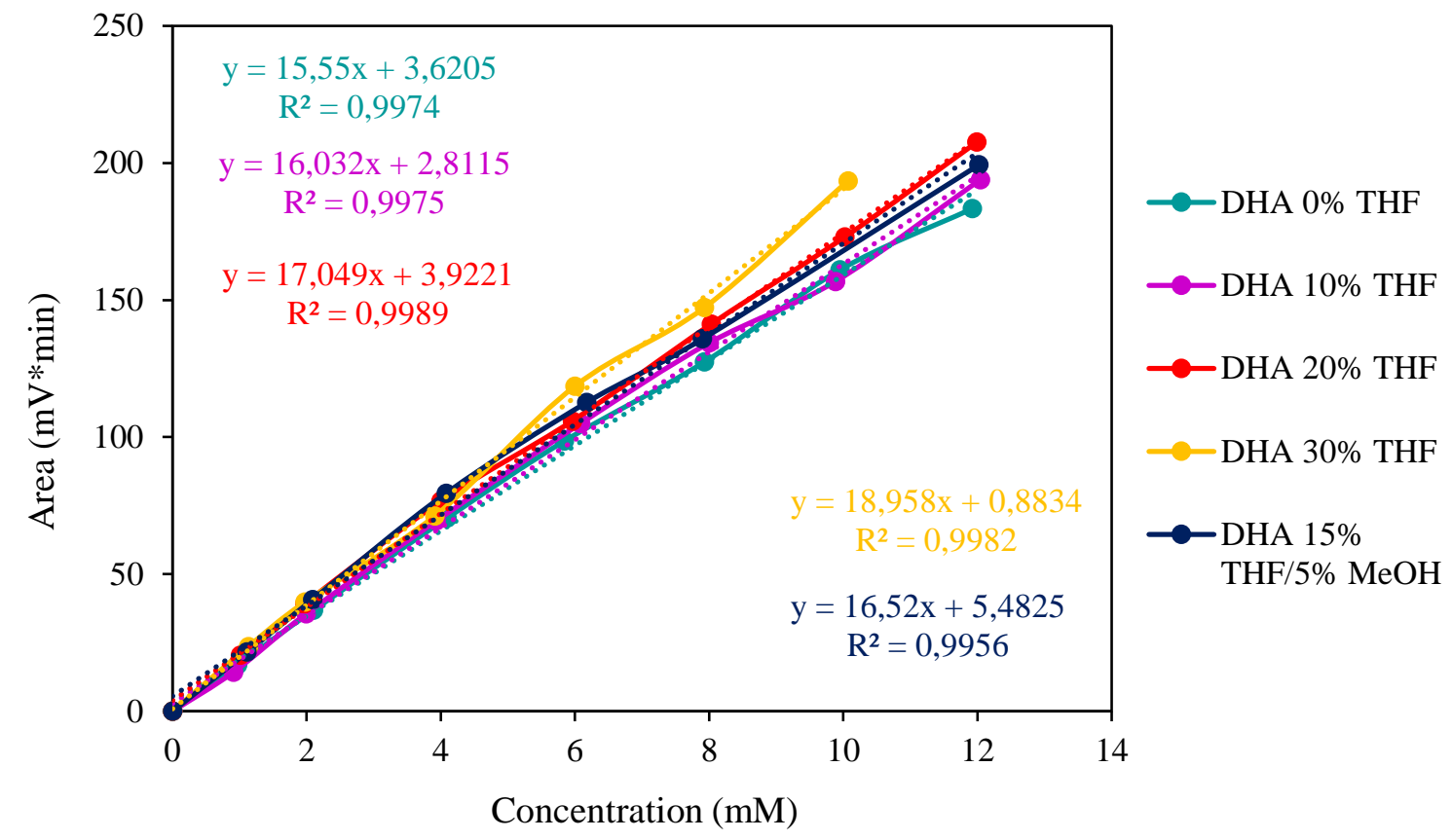

Figure S33. Calibration curve for the determination of the concentration of (DHA). 


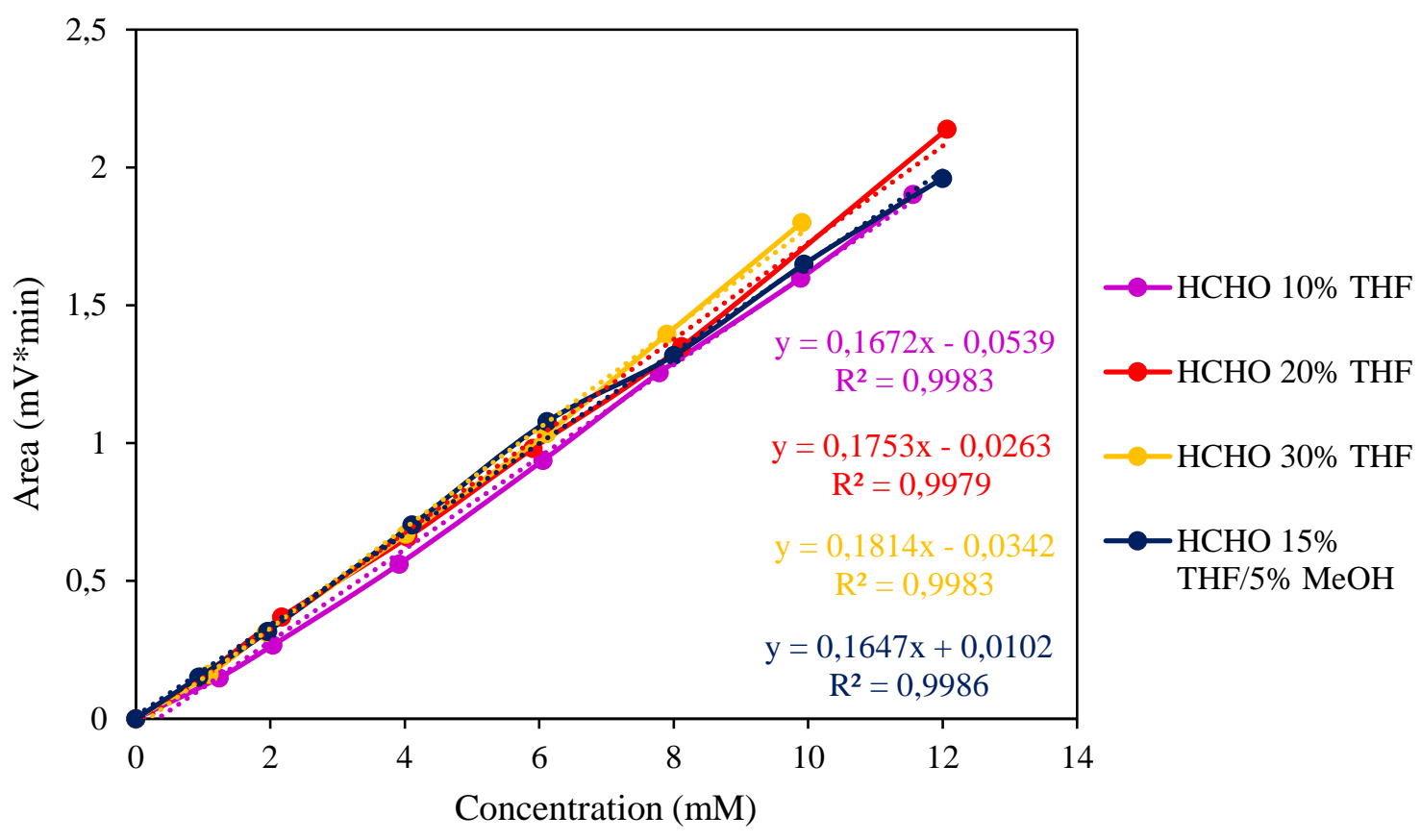

Figure S34. Calibration curve for the determination of the concentration of formaldehyde. 


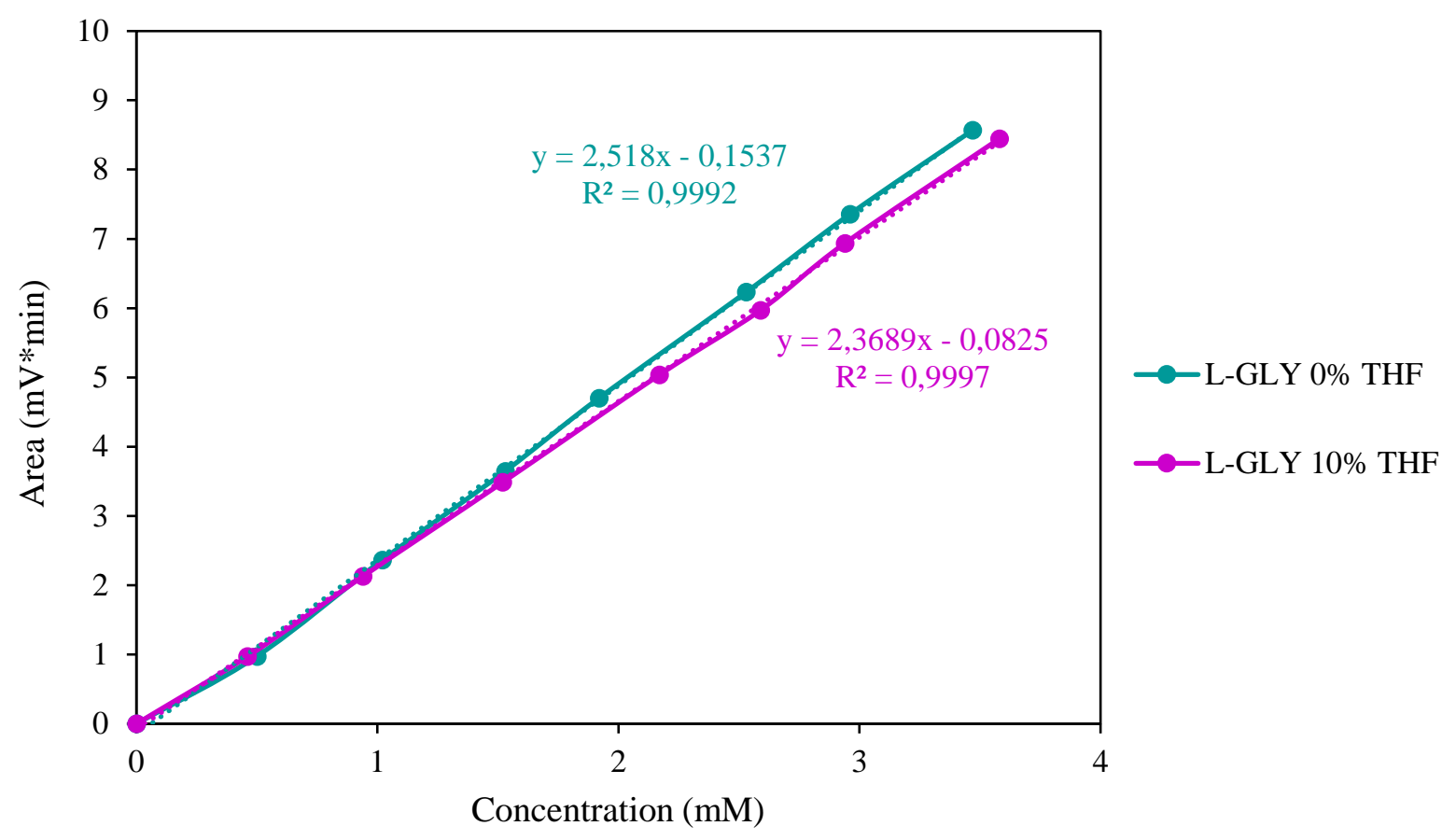

Figure S35. Calibration curve used to determine the concentration of L-glyceraldehyde.

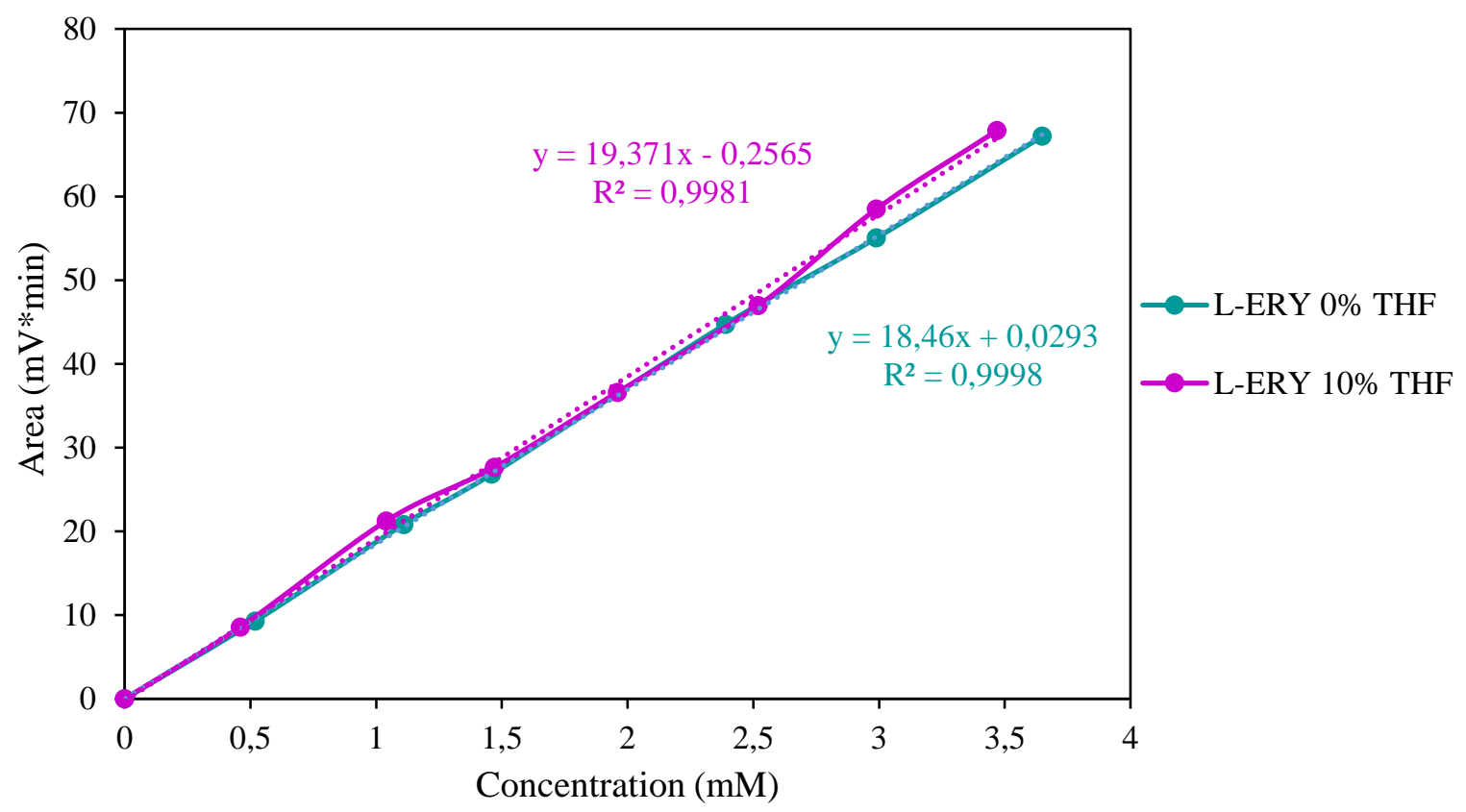

Figure S36. Calibration curve used to determine the concentration of L-erythrulose. 


\section{Retention time of the standards}

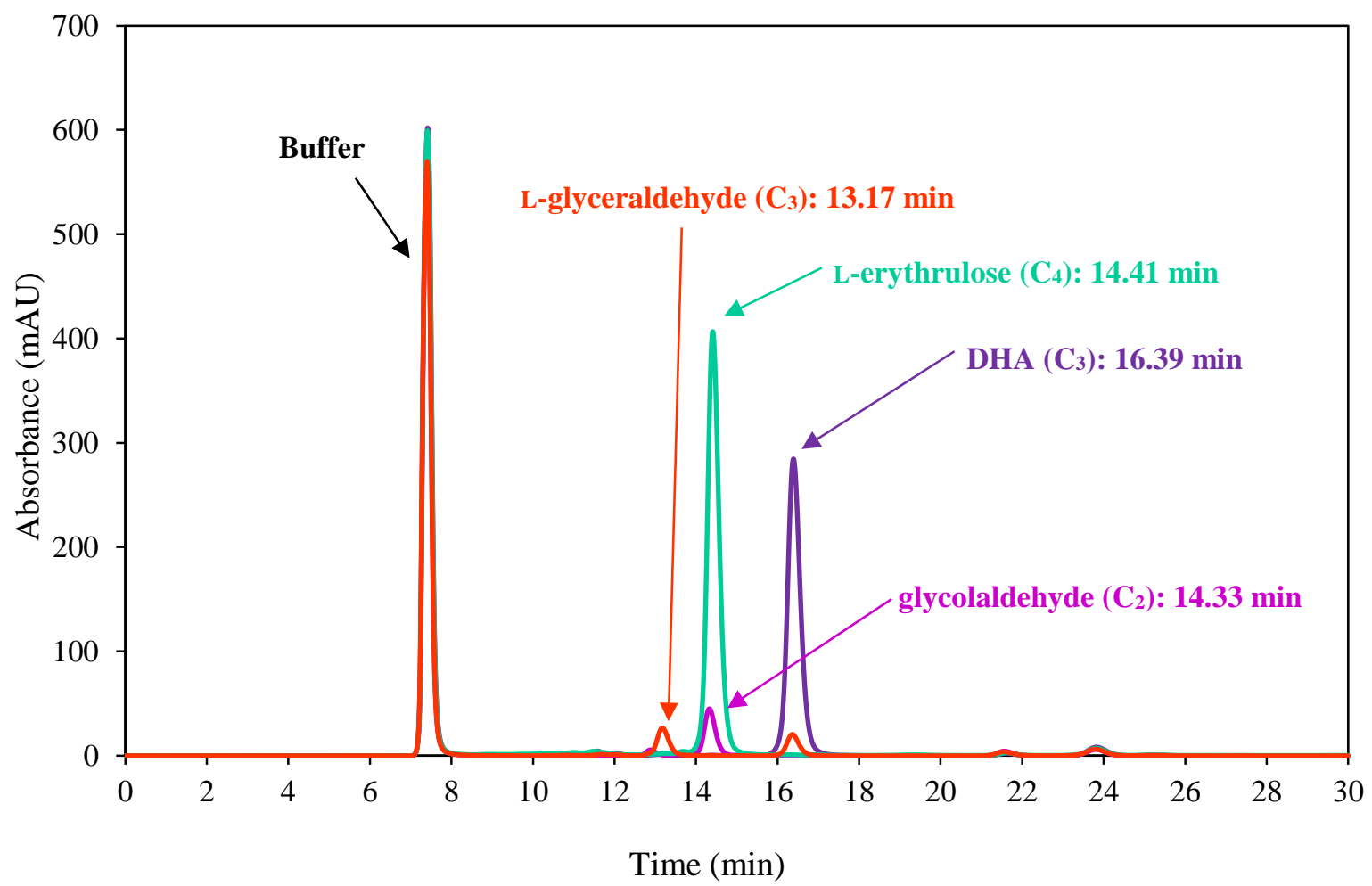

Figure S37. HPLC chromatogram of the standards: DHA and glycolaldehyde at $8.5 \mathrm{mM}$ and L-erythrulose and L-glyceraldehyde at $6.5 \mathrm{mM}$ (UV detector $192 \mathrm{~nm}$ ).

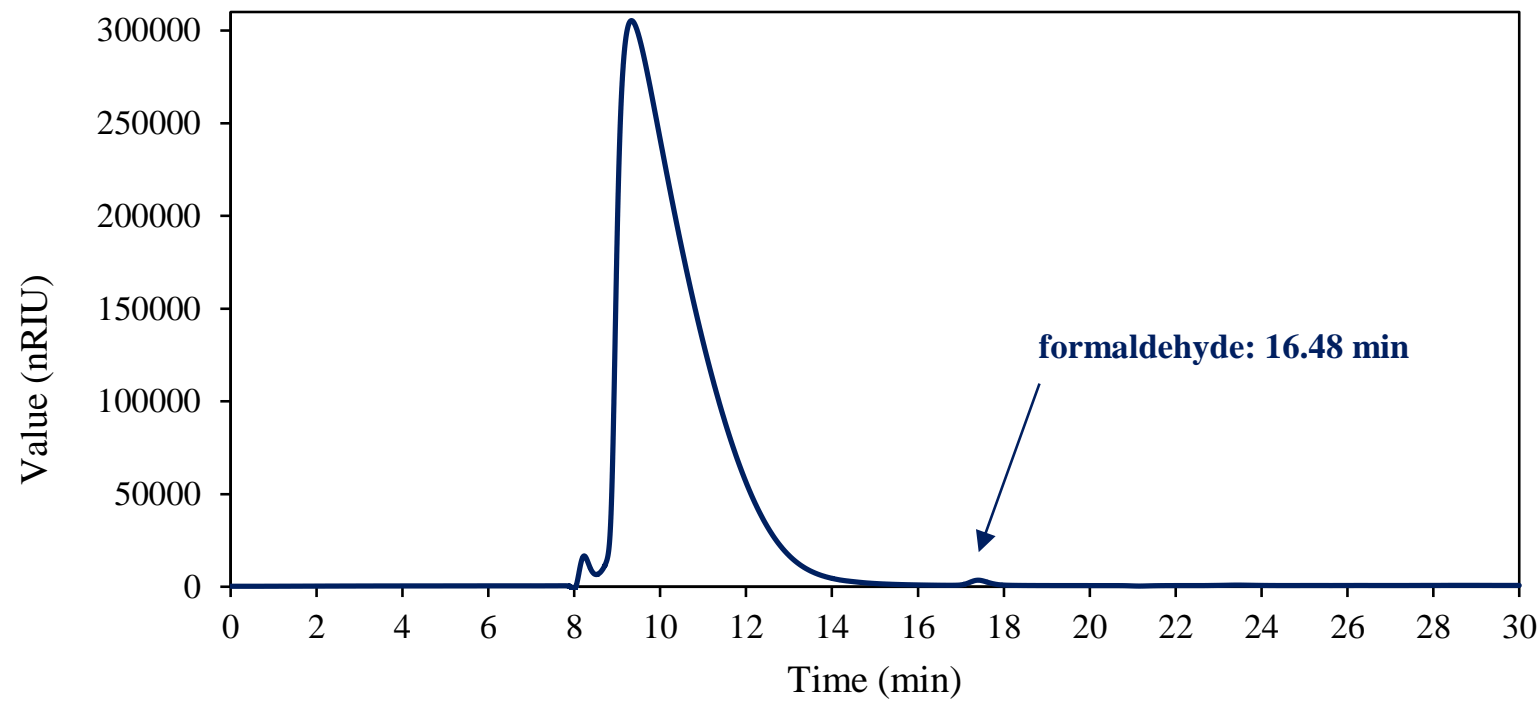

Figure S38. HPLC chromatogram of formaldehyde at $10 \mathrm{mM}$ (RI detector). Formaldehyde was not detected under UV. 
18. Purification of FLS and FSA A129S: SDS-PAGE analysis

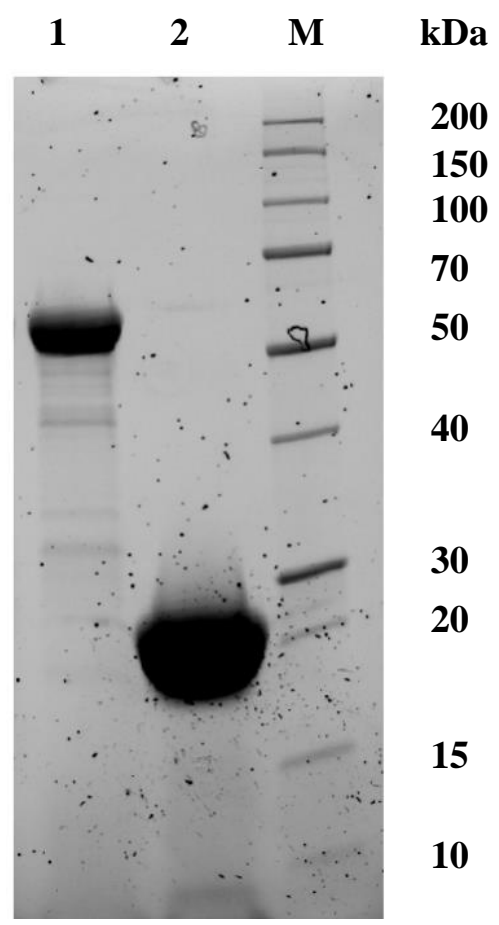

Figure S39. SDS-PAGE analysis of purified FLS (61.4 kDa) and FSA A129S (23 kDa). 1: Purified FLS, 2: Purified FSA A129S, M: Molecular weight size marker. 


\section{References}

(1) SAINT Bruker (2007). Bruker AXS Inc., Madison, Wisconsin, USA.

(2) CrysAlisPro 1.171.38.43b (Rigaku Oxford Diffraction, 2015).

(3) Sheldrick, G. M. A Short History of SHELX. Acta Crystallogr. A 2008, 64 (1), 112-122. https://doi.org/10.1107/S0108767307043930.

(4) Farrugia, L. J. WinGX Suite for Small-Molecule Single-Crystal Crystallography. J. Appl. Crystallogr. 1999, 32 (4), 837-838. https://doi.org/10.1107/S0021889899006020.

(5) Cromer and J, D. T.; Waber, T. International Tables for X-Ray Crystallography. Vol IV Kynoch Press Birm. Engl. 1974, 99.

(6) Blessing, R. H. Acta Crystallogr., Sect. A. A51 1995, 33-38.

(7) Farrugia, L. J. ORTEP-3 for Windows - a Version of ORTEP-III with a Graphical User Interface (GUI). J. Appl. Crystallogr. 1997, 30 (5), 565-565. https://doi.org/10.1107/S0021889897003117.

(8) Gutierrez, M.; Parella, T.; Joglar, J.; Bujons, J.; Clapés, P. Structure-Guided Redesign of DFructose-6-Phosphate Aldolase from E. Coli: Remarkable Activity and Selectivity towards Acceptor Substrates by Two-Point Mutation. Chem. Commun. 2011, 47 (20), 5762-5764. https://doi.org/10.1039/C1CC11069A.

(9) Siegel, J. B.; Smith, A. L.; Poust, S.; Wargacki, A. J.; Bar-Even, A.; Louw, C.; Shen, B. W.; Eiben, C. B.; Tran, H. M.; Noor, E.; Gallaher, J. L.; Bale, J.; Yoshikuni, Y.; Gelb, M. H.; Keasling, J. D.; Stoddard, B. L.; Lidstrom, M. E.; Baker, D. Computational Protein Design Enables a Novel OneCarbon Assimilation Pathway. Proc. Natl. Acad. Sci. 2015, 201500545. https://doi.org/10.1073/pnas.1500545112.

(10) Poust, S.; Piety, J.; Bar-Even, A.; Louw, C.; Baker, D.; Keasling, J. D.; Siegel, J. B. Mechanistic Analysis of an Engineered Enzyme That Catalyzes the Formose Reaction. ChemBioChem 2015, 16 (13), 1950-1954. https://doi.org/10.1002/cbic.201500228.

(11) Castillo, J. A.; Guérard-Hélaine, C.; Gutiérrez, M.; Garrabou, X.; Sancelme, M.; Schürmann, M.; Inoue, T.; Hélaine, V.; Charmantray, F.; Gefflaut, T.; Hecquet, L.; Joglar, J.; Clapés, P.; Sprenger, G. A.; Lemaire, M. A Mutant D-Fructose-6-Phosphate Aldolase (Ala129Ser) with Improved Affinity towards Dihydroxyacetone for the Synthesis of Polyhydroxylated Compounds. Adv. Synth. Catal. 2010, 352 (6), 1039-1046. https://doi.org/10.1002/adsc.200900772.

(12) Yang, J.; Sun, S.; Men, Y.; Zeng, Y.; Zhu, Y.; Sun, Y.; Ma, Y. Transformation of Formaldehyde into Functional Sugars via Multi-Enzyme Stepwise Cascade Catalysis. Catal. Sci. Technol. 2017, 7 (16), 3459-3463. 